\title{
مفهوم الأُمَّة وأوصافها في القرآن الكريم
}

\section{*وفيق البدري}

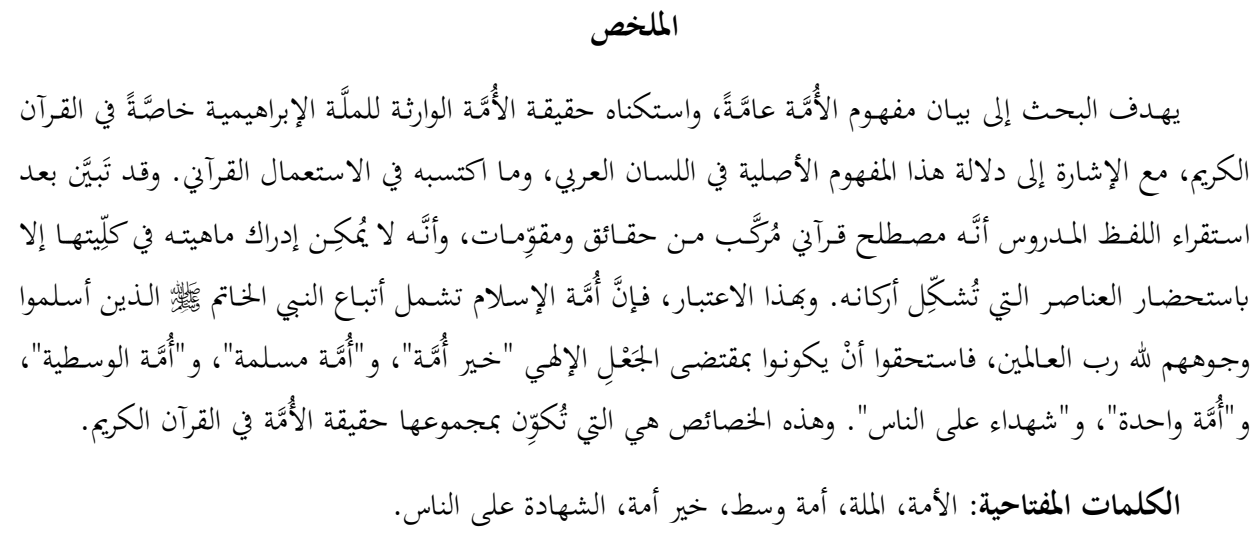

The Concept of Ummah and its Descriptions in the Holy Quran

Taoufik Elbadri

\begin{abstract}
The purpose of this study is to demonstrate the concept of Ummah, in general and the essense of the Ummah who has inherited the faith of Prophet Ibrahim as explained in the Holy Quran, with reference to the original meaning of ummah in the Arabic tongue, and it has acquired in the Quranic usage. The scrutiny of the concept has revealed that it is a Qur'anic term composed of certain facts and has certain pillars, and it is difficult to get into its essense without recalling these facts and pillars.

With this consideration, the Ummah of Islam includes the followers of Prophet Muhammad, peace be upon him, who turned their faces to Allah the Lord of the Worlds. Upon this kind of faith those followers deserve to have the Devine decree to be considered the "best ummah", the "Muslim ummah", the moderate ummah", the "one ummah" and the ummah whose members are "witnesses to mankind" These characteristics all together constitute the reality of the ummah in the Holy Quran.
\end{abstract}

Keywords: Ummah; Community of faith, Ummah of Moderation and Balance; Best Ummah; Witness to mankind.

$$
\begin{aligned}
& \text { * دكتوراه في الفكر الإسـلامي والحضـارة، جامعة سيدي محمد بـن عبد الله، فـاس - المغرب، الأكاديمية الجهويـة للتربية }
\end{aligned}
$$

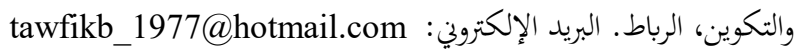

$$
\begin{aligned}
& \text { تم تسلم البحث بتاريخ 2018/1/13م، وقُبل للنشر بتاريخ الإيخ 2018/8/26م. }
\end{aligned}
$$


مقدمة:

عرض القرآن الكريم لمفهوم كلِّ من الأُمَّة، والأُمَّة المسلمة، وتناوهمـا في العديد مـن

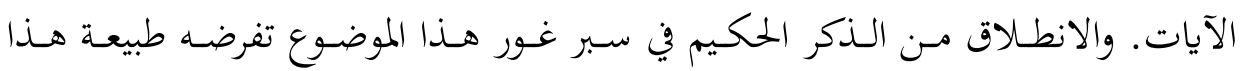

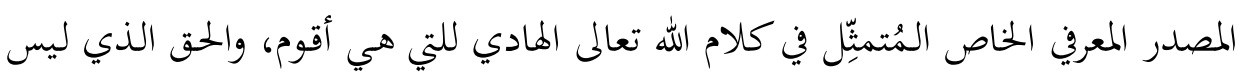

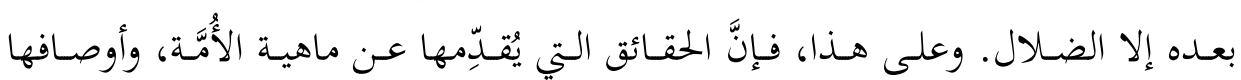

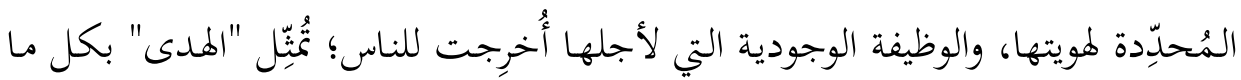

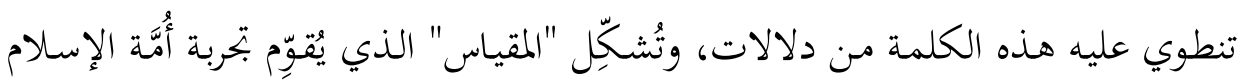

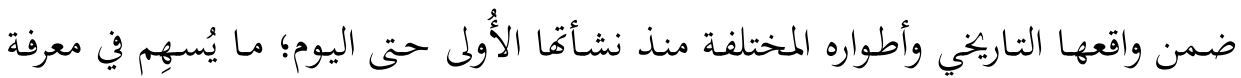

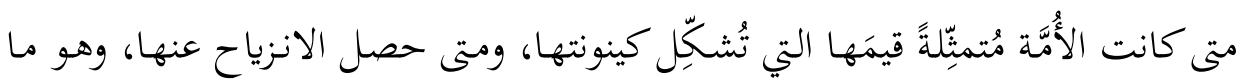

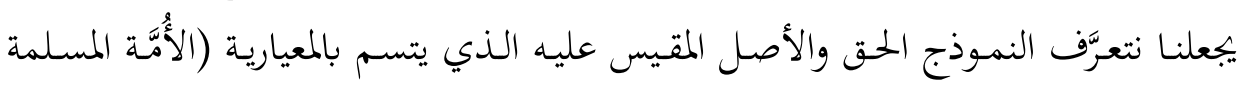

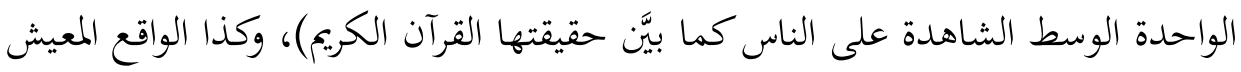
(الأُمَّة الإسلامية في صورةا التاريخية والمعاصرة) الذي يتطلَّب التقويم المستمر. وسعياً إلى إدراك بعض البصـائر القرآنيـة المتصـلة بمفردة "الأُمَّة"؛ فـإنَّ البحـث يـروم الإجابة عن الأسئلة الآتية: إلدرئ - ما دلالات مفردة "الأُمَّة" في اللسان العربي؟ - ما مفهومها في القرآن الكريع؟

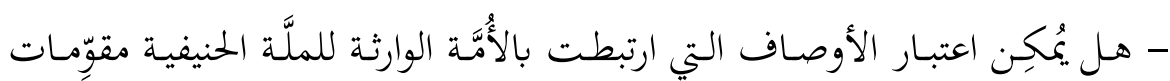
متلازمة تُشكِل في المحصلة ماهيتها؟ - هل تقتضي تلك الأوصاف تكليفاً شرعياً ذا وظيفة حضارية مُفترَضة لهذه الأُمَّة؟ والغـرض الأسـاس مـن درس هـذا المفهـوم القــرآي هـو الإسـهام -ولـو بمقـدارٍ - في

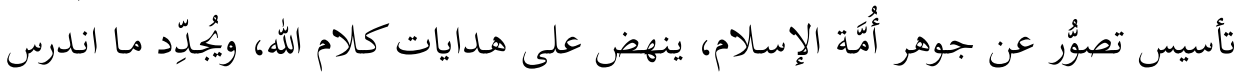

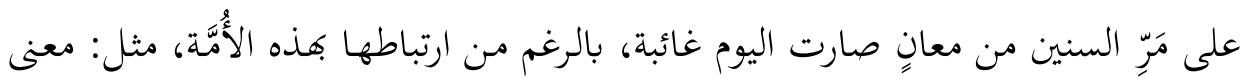


إسلام الوجهه الله تعالى في بُعْده الجماعي، ومعنى الوسطية، ومعنى إلحاق الرحمة بالناس، وغير ذلك من التكاليف المنوطة بالأُمَّة قدراً وشرعاً. ولا شــكَّ في أنَّ هـذا الاستكشـاف لمفهـوم "الأُمَّـة" سـيزيل عنـه ركامـاً مـن التشـويه

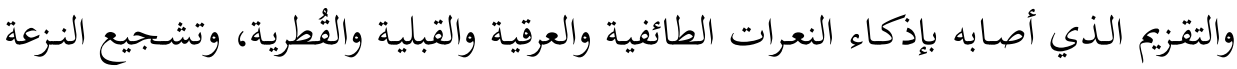

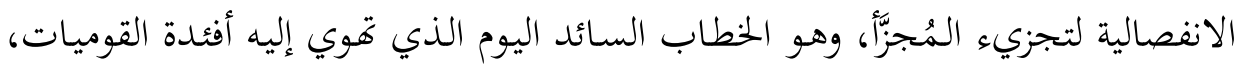

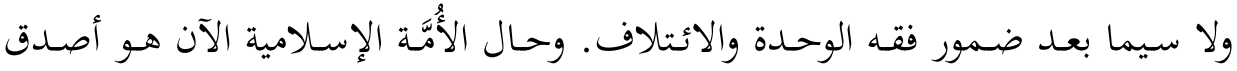

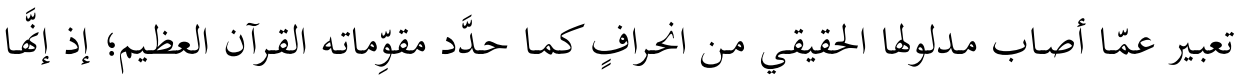

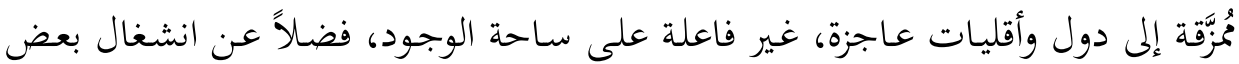

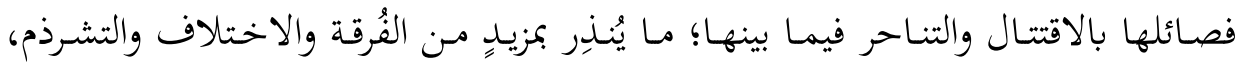
ذلك أنَّ دواعيه تبدو عميقة الجذور، وتمتد إلى أغوار النفس والفكر، وهذا وها يُهُّتِّم علينا إبراز

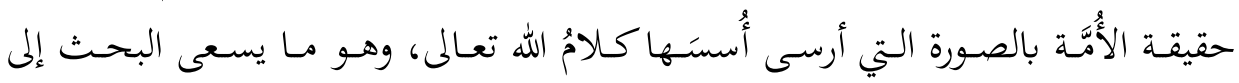
الكشف عن بعض جوانبه.

وتظهر فائـدة البحـث في انطلاقـه مـن نصـوص القـرآن الكـريم ابتـاءً؛ فهي مادتـه

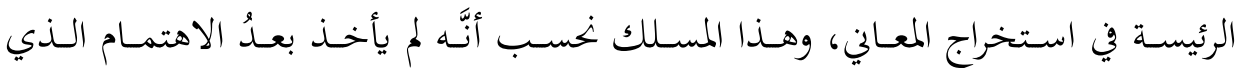
يستحق في ساحتنا العلمية؛ لأنَّ دعوى اعتبار القرآن مصدر المعرفة ستظل بلا أثر إذا لم

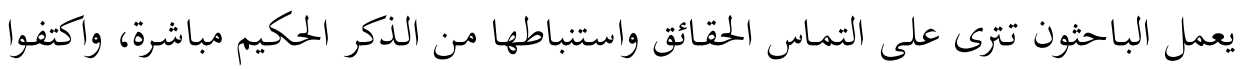

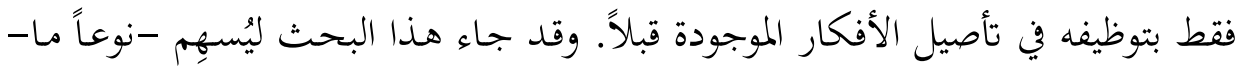
في إغناء ذلك المنهج، ويغترف من مَعِين الكتاب العزيز، على سبيل التدبر في الآيات التي

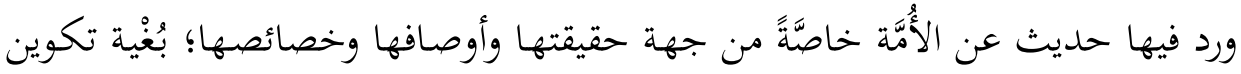

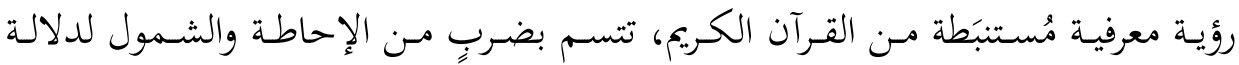
"الأُمَّة" بوصفها ذاتاً، ومضمونةاً، وتكليفاً، وقيماً.

والحقيقة أنَّ ثنَّة جهوداً كثيرةً سابقةً تناولت المسألة من منظور قرآني خالص، وأفردها

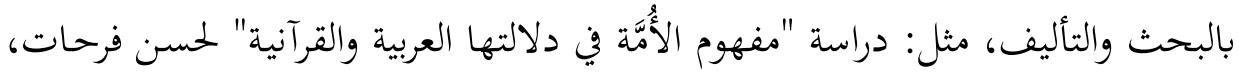
وهي دراسة بحثت في دلالة لفظ "الأُمَّة" في الاستعمال اللغوي ومفهومه في القرآن الكريم 


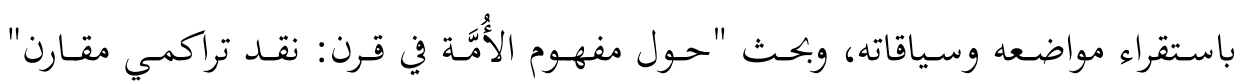

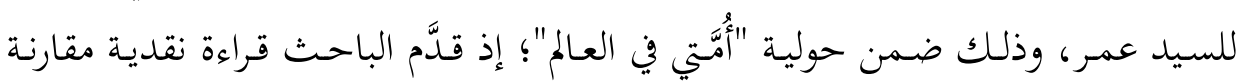

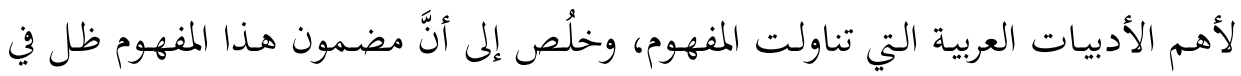

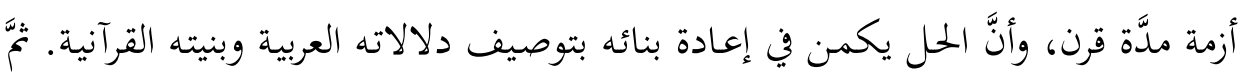

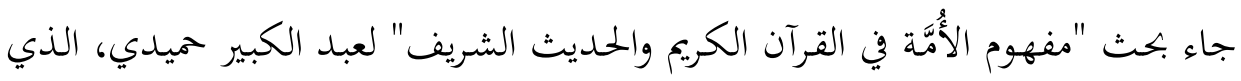

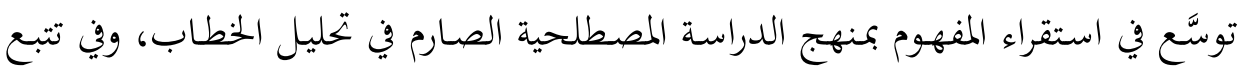

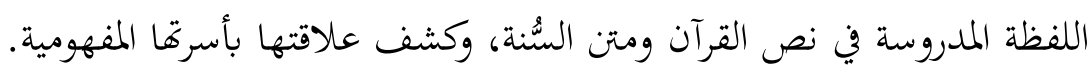
ومـن الإسهامات الأُخرى في تأصيل هـذا المفهـوم كتـاب "الأُمَّة القطب" لمنى أبو

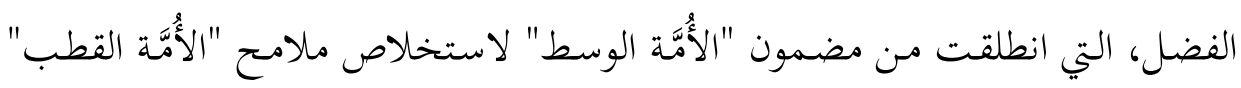
بوصفها نقطة إشعاع وجذب على المستوى الداخلي، ومركز احتواء وصهر على المستوى

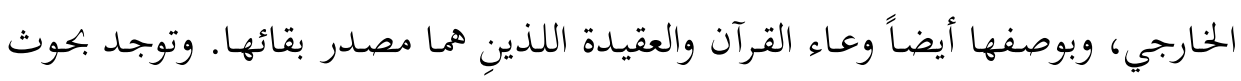

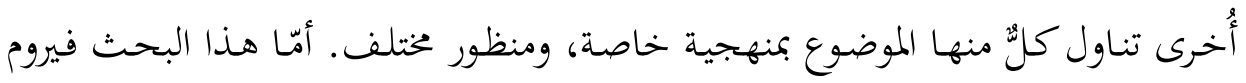

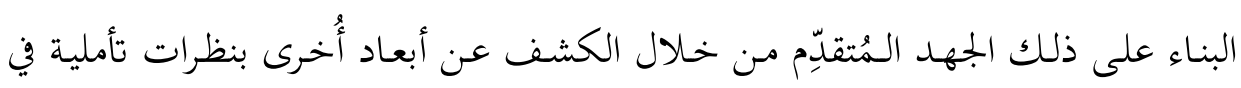
المفهوم، عن طريق الجمع بين معنى اللفظ في اللسان العربي ومعناه في السياق القرآني، والأوصاف التي تعلَّقت به وأكسبته دلالات متفرّدة، وكذا النظر إلى طبيعة الوظيفة التي

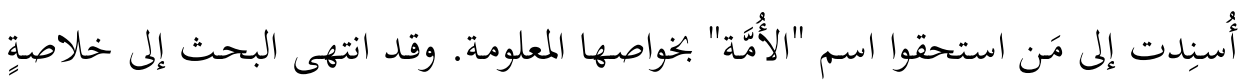
مفادها أنَّ لفظ "الأُمَّة" هو مصطلح قرآين مُركَّب، له متعلقَات وحقـائق متكاملة، وأنَّ معناه الكلي لا يُدرَك إلا باستحضار جميع المقوِّمات المُكوِّنة لماهيته كما سيأتي بيانه. وفيمـا يخص المـنهج السمُتَّبَع في البحـث، فإنَّهـ يعتمـد أساسـاً على المـنهج الوصفي

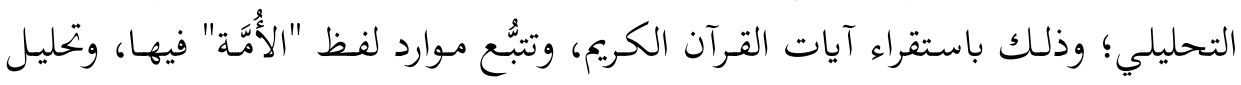

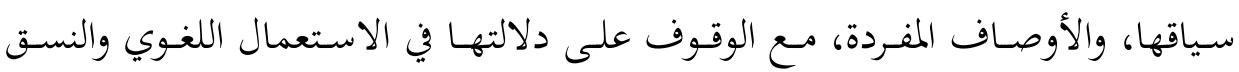




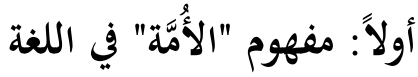

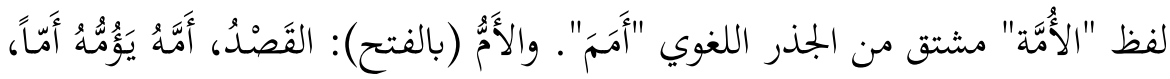

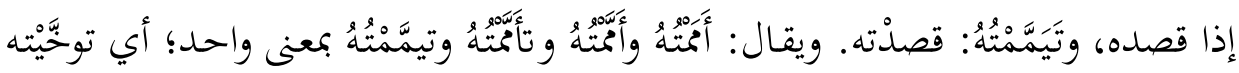

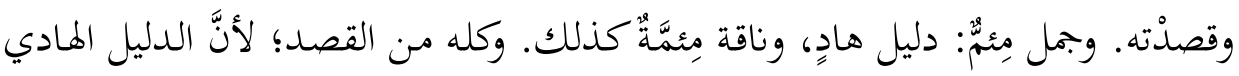

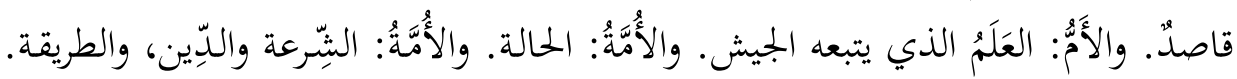

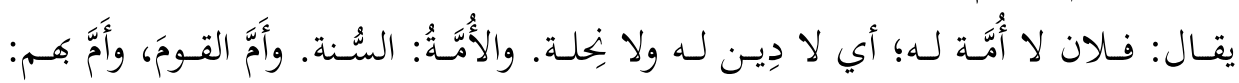

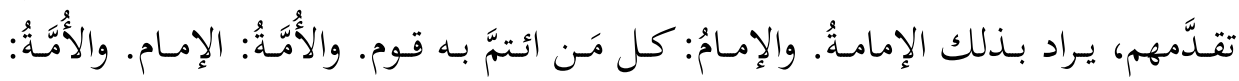

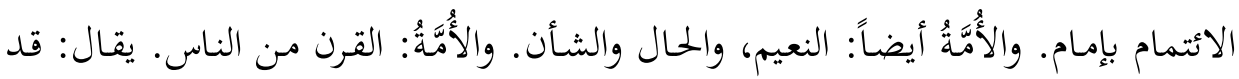

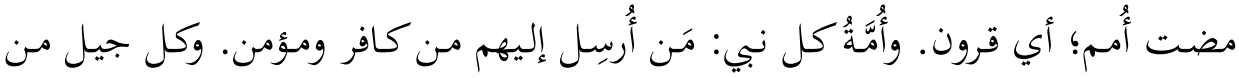

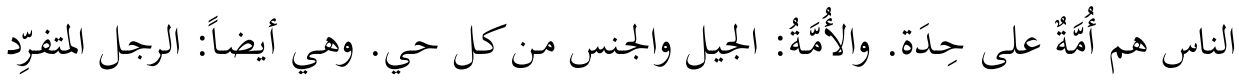

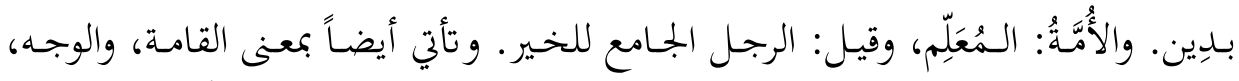

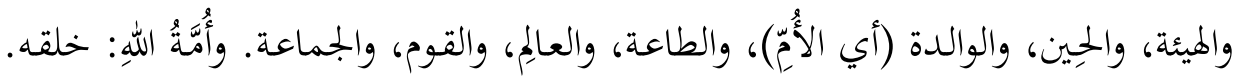

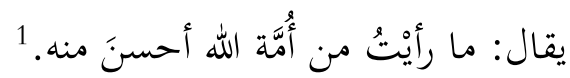

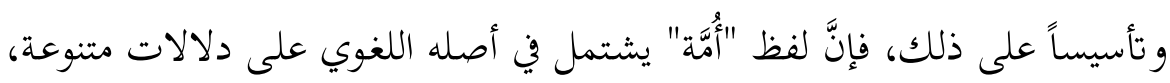

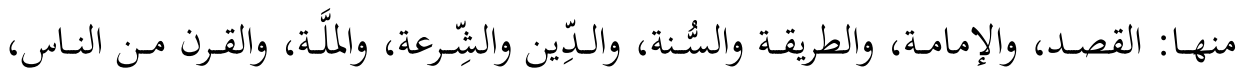

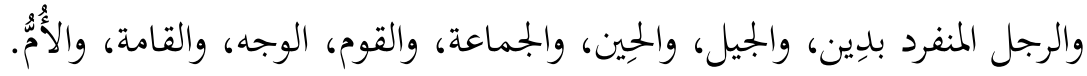

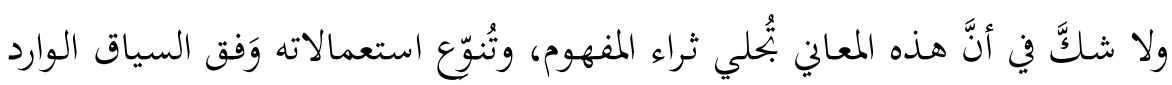

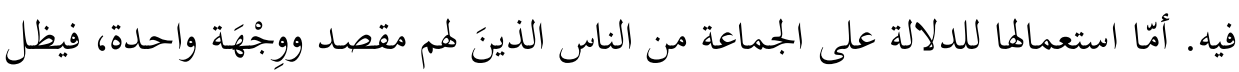

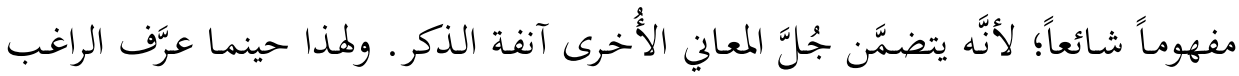

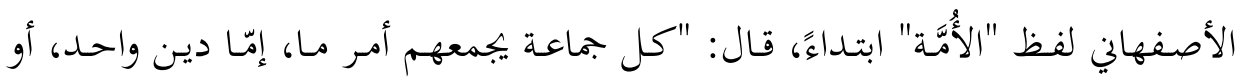

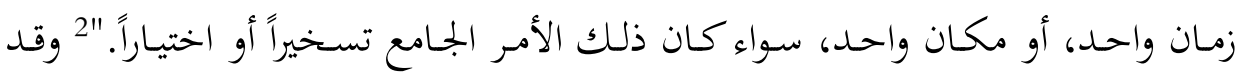

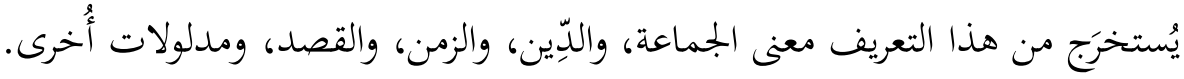

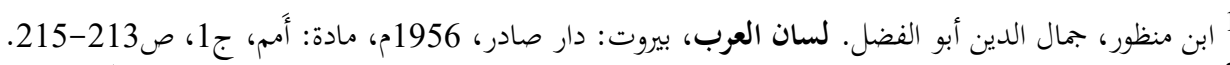

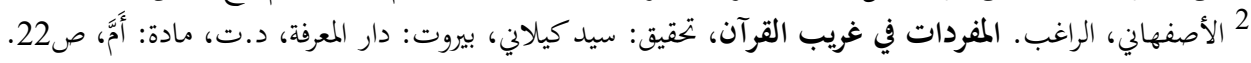


وإذا أمعنا النظر في تلك المعاني اللغوية، فإنَّهُ يُمِكِنا ردُّ أغلبها إلى الأصول الآتية: 1. القصد: ذلك أنَّ لفظ "الأُمَّة" مشتق من "الأَمِّ"؛ أي القصد. يقال: أَمَتْهُ إليه،

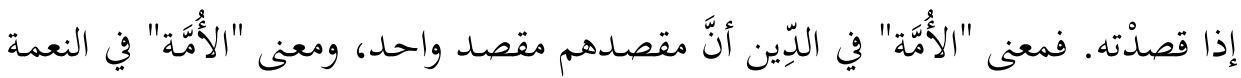

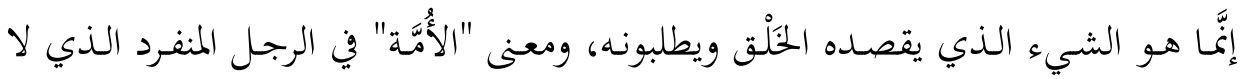

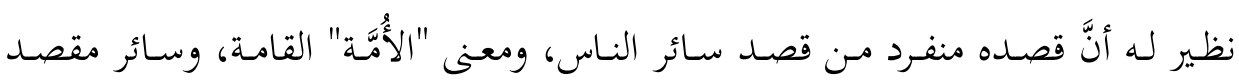

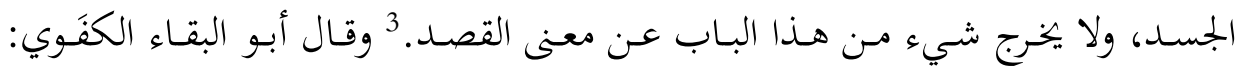

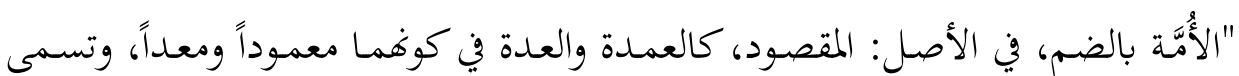
بهـا الجماعـة مـن حيث تؤمها الفرق. "4 ويفيد القصد معنى استقامة الطريق، ومنه قوله

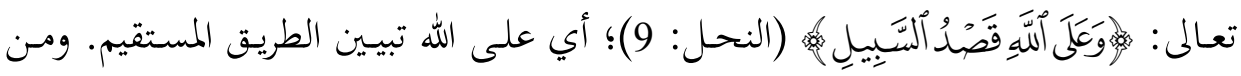

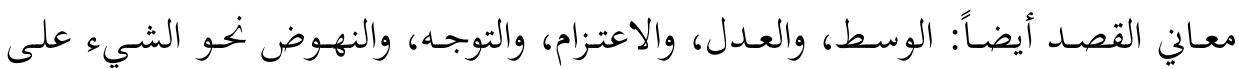
اعتدال واستقامة من دون ميل.

2. الأصل: ذلك أنَّ الممزة والميم أصل واحد، يهيل إلى فروع دلالية، منها: الأصل، والمرجع.' وكل مـاكان أصلاً لوجود شيء، أو تربيته، أو إصلاحه، أو مبدئه، يقال له:

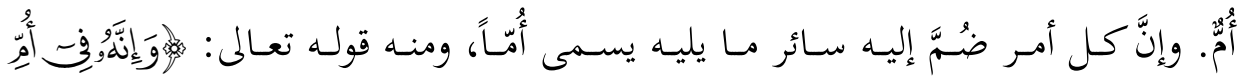

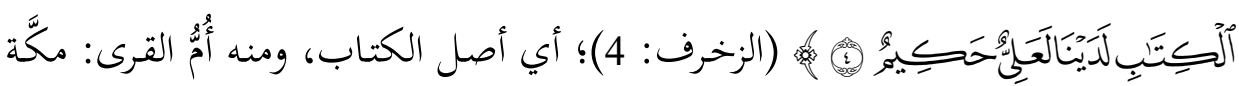

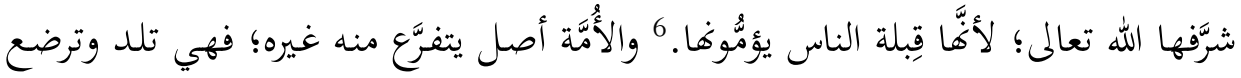
وتحتضن، ويتلازم الِبرٌ إليها مع التوحيد، ولا يسبق الإحسان إليها إلا هو.

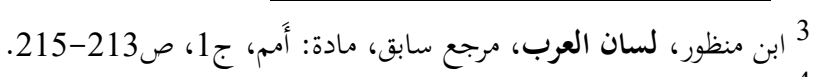

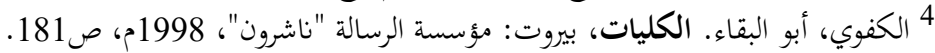

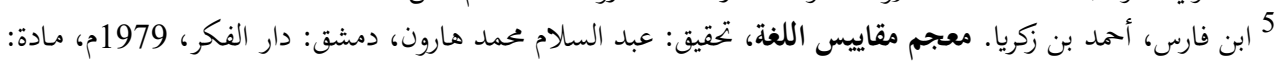

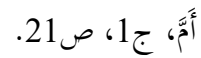

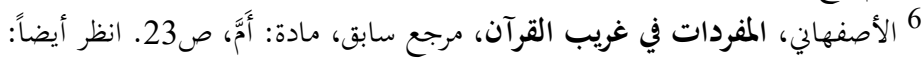

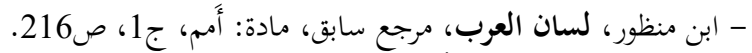

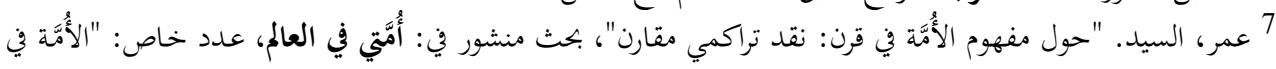

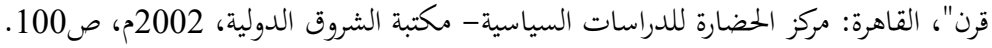


3. جماعة بشرية مجتمعة على أمر جامع: يتبادر هذا المعنى إلى الذهن عند إطلاق

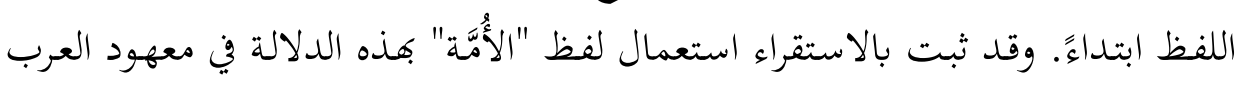

$$
\text { في الخطاب بصورة كبيرة. }
$$

4. الدِّين: يشمل ذلك معنى الطاعة، والشّرِعة، والطريقة، والملَّة، والسُّنة، وكذا الأمر

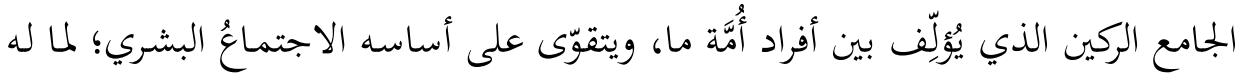

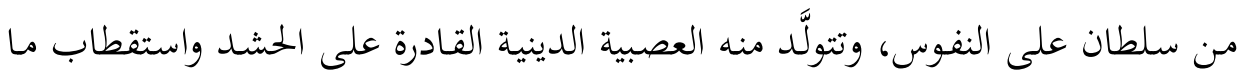

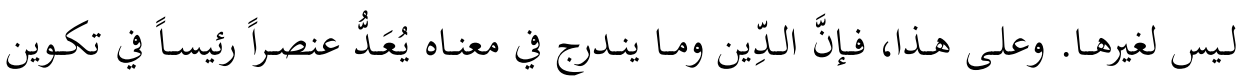
الأُمَّة.

5. الزمن: هو اسم لقليل الوقت وكثيره، وظرف كل الأمم ووعاؤها؛ فلكل أُمَّة حين من الدهر توجد فيه، وأجل معلوم عند الله تعالى تمضي إليه. وخلاصة القول إنَّ لفظ "الأُمَّة" عريق في اللسان العربي، غني حافل بالمعاني العميقة،

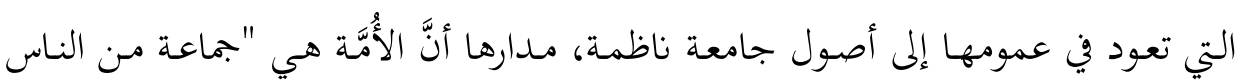

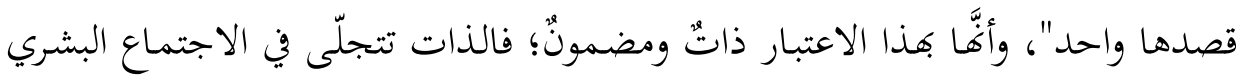
قَلَّ أو كثر، والمضمون يتمثَّل في القصد الجامع، وما ينطوي عليه من دِين وطريقة وشِرعة.

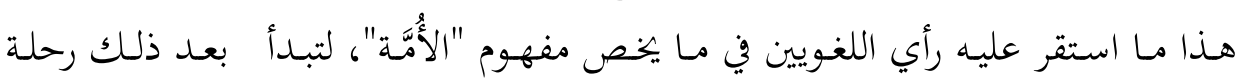
البحث عن دلالته في القرآن الكريم.

\section{ثانياً: مفهوم "الأُمَّة" في القرآن الكريم}

ورد لفظ "الأُمَّة" اسمـاً مفرداً بالتنكير والتعريف سبعاً وأربعين مسرَّة في القرآن الكريم،

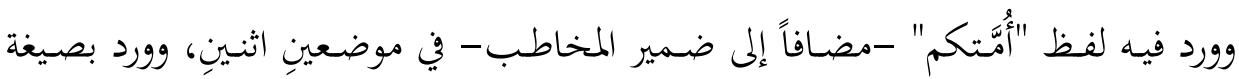

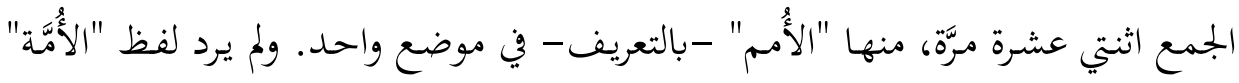
بهذه الصورة؛ أي مفردة مُعََّّة بالألف واللام. 8 8 8جمع اللغة العربية. معجم ألفاظ القرآن الكريم، القاهرة: الميئة العامة لشؤون المطابع الأميرية، 1989م، مادة: أمم،

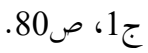


وبعد استقراء تلك المواضع، بدا أنَّا تأتي بالمعاني الآتية:

1. جماعة من الجنس البشري مجتمعة على دِينٍ حق، أو اعتقاد باطل: الآيات التي جاءت فيها كلمة "أمَّة" بهذا المعنى كثيرة، منها قوله تعالى: -

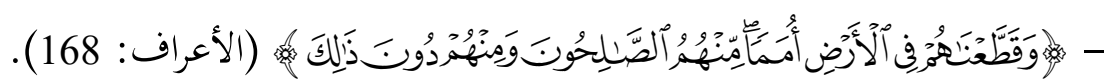

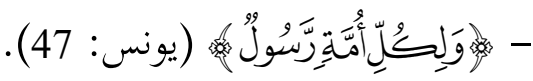

$$
\begin{aligned}
& \text { - } \\
& \text { - }
\end{aligned}
$$

والـمُلاحَظظ أنَّ كلمـة "أُمَّة" في الآيات الكريمة قـــ وردت بمعناهـا الأصلي في اللسـان

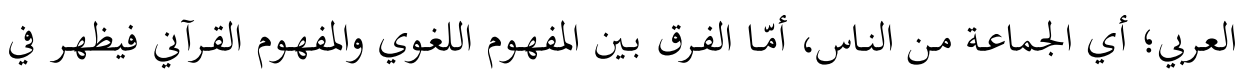
السياق الجديد؛ إذ أصبح لهذه المفردة صبغة ربانية في الكتاب المبين، تُعبِّر عن مراد الله -

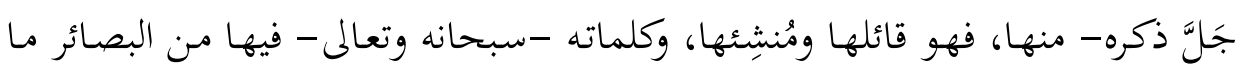
لا يجصى، وتلك خصيصة المفاهيم القرآنية التي تخدم جميعها مقصد الهداية.

وقد تأتي أيضاً بمعنى الطائفة المتميزة من الجماعة الكبيرة الأُمّ؛ وهي القوم. فقد أخبر

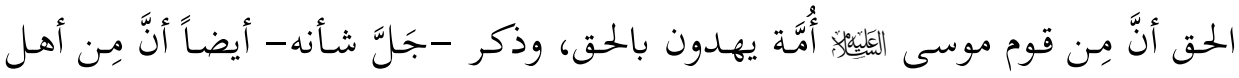

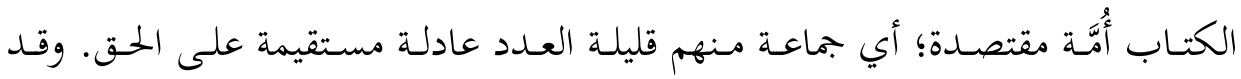

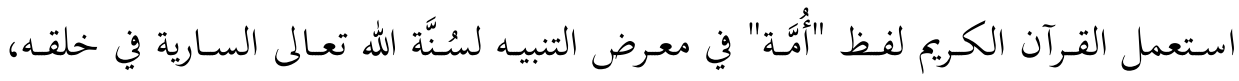

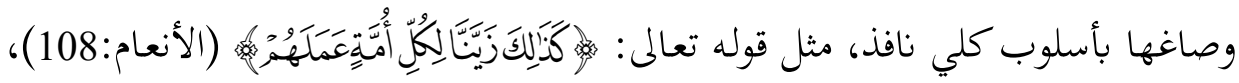

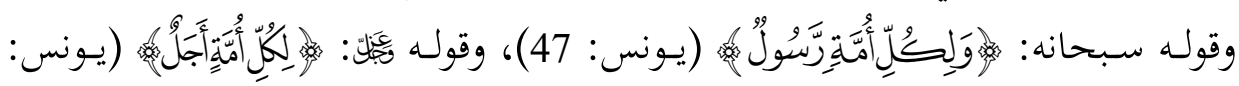

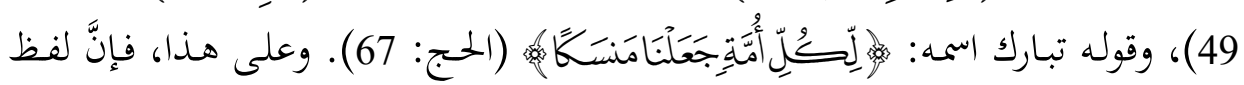


"الأَُّّة" في هذه السياقات لم يأتِ إلا بمعنى الجماعة الإنسانية الجمتمعة على أمر جامع قد يكون حقّاً أو باطلاً

\section{2. جماعات من أحياء وكائنات ليست من جنس البشر:}

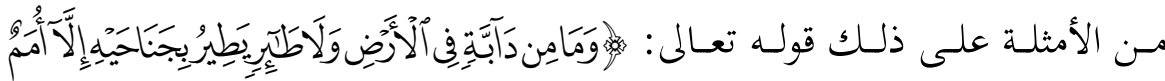

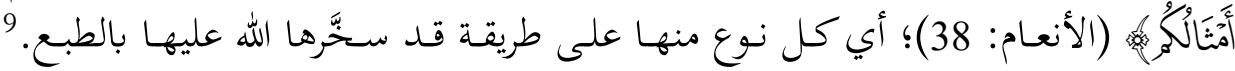
وأمثالكم صفة لِِأمهم، يعني أمثالهم في الأرزاق والآجال، والموت والحياة، والحشر والنشر. وقيل: في معرفـة الله وعبادته. "10 ولم يـذكر الحـق -سبـحانه- طبيعـة المماثلـة القائمـة بـين

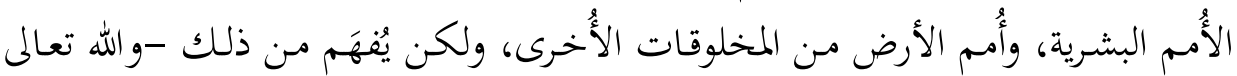

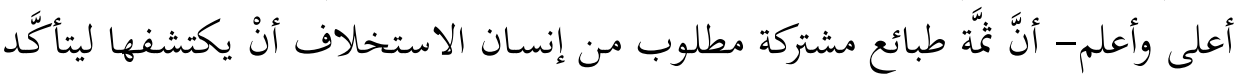

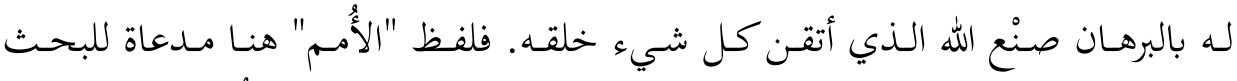
العلمي وإثارة عقل الإنسان لكي يهفر ويُنِِّب عن السنن الحاكمة في الأُمْ المماثلة لنا. 3. جماعة من الناس مُستسلمِة لله تعالمى:

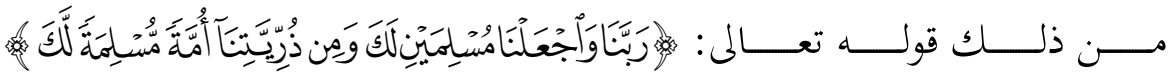
(البقرة:128). ولم يرد في القرآن الكريم لفظ "أمَّة" بهذا الوصف البليغ إلا في هذه الآية، والمـراد جماعـة مـن النـاس مؤمنـة بـرب العـالمين، منقـادة لـه حقيقـة وليس ادِّعـاء. وسـيأتي تفصيل هذا المعنى في موضعه لاحقاً.

\section{4. أُعَّة محمد :}

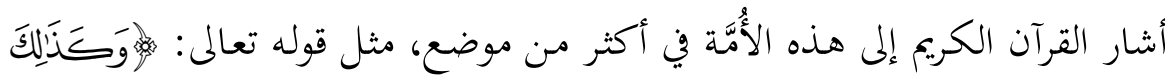

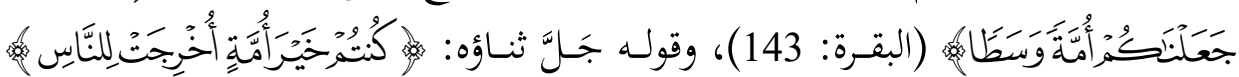
(آل عمران: 110). والسياق في هاتين الآيتين يدل على أنَّ الأُمَّة المقصودة هنا هي الأُمَّة

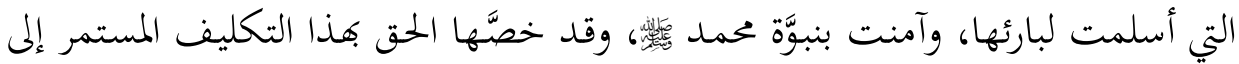
يوم الدِّين، ويْي هذا تفصيل سيذكر بعدُ في محلّه.

9 الأصفهاني، المفردات في غريب القرآن، مرجع سابق، ص68.

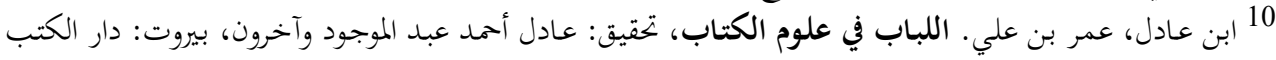




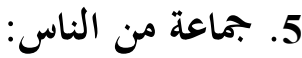

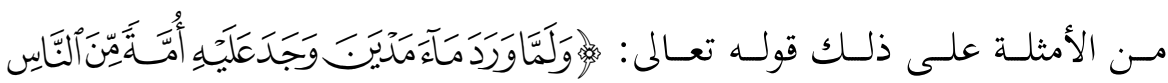

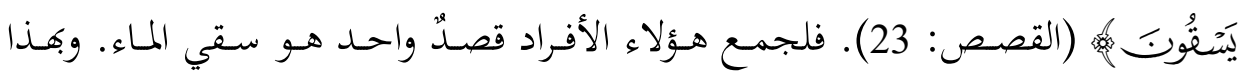
الاعتبار، فإِهَّم أضحوا أُمَّة مجتمعة على أمر مُعيَّن.

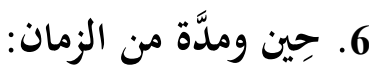

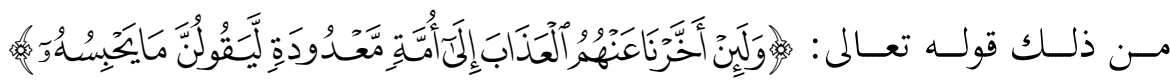
(هود: 8). قال الطبري: "أُمَّة معدودة أي وقت محدود وسنين معلومة، وأصل الأُمَّة أفَّا

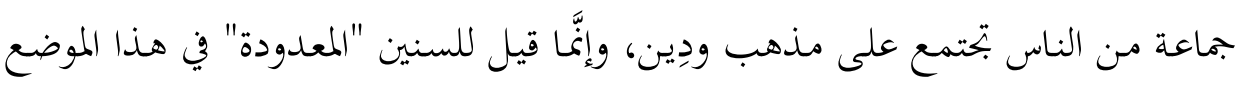
أُمَّة؛؛ لأنَّ فيها تكون الأُمَّة.

وثمَّة تلازم بين الزمن والأُمَّة؛ فالسنين ظرف للأُمْم. وقد عبََّّ القرآن الكريم في آيات

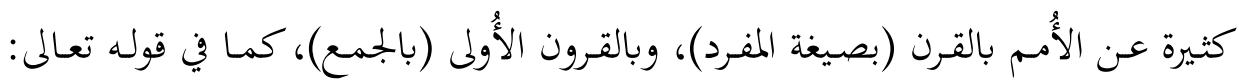

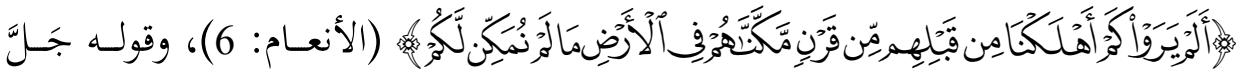

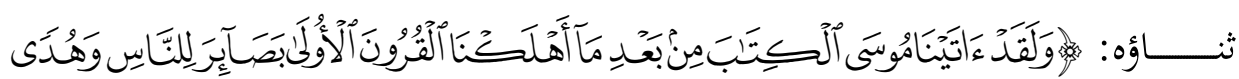

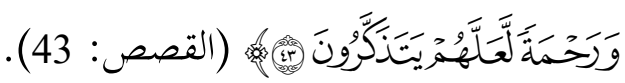

والقـرن اسـم لمـدَّة مـن الزمـان على اخستلافٍ في تحديـدها، وقيـل: مئسة سـنة، وهـو

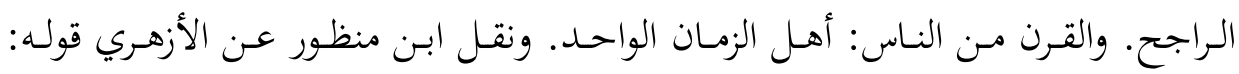

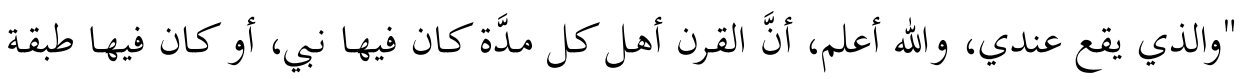

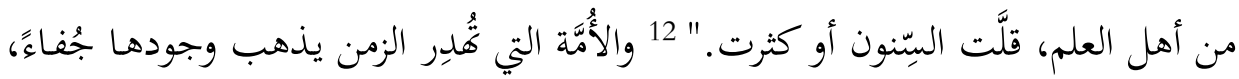

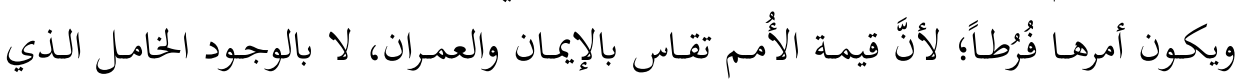

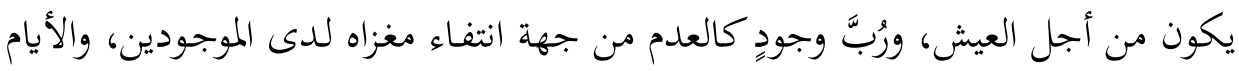
عند هؤلاء متساوية فارغة بلا مضمون ولا إنجاز .

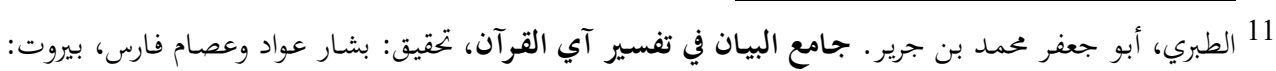

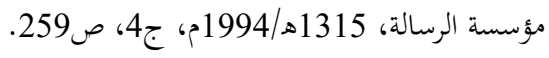

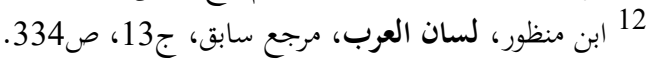




\section{7.}

من الأمثلة على ذلك قوله تعالى :

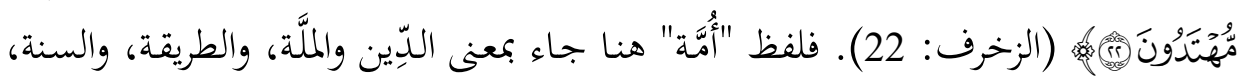

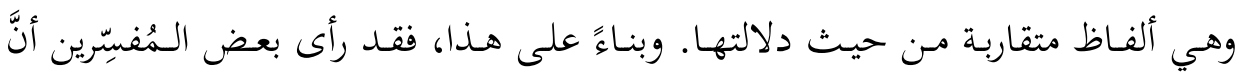

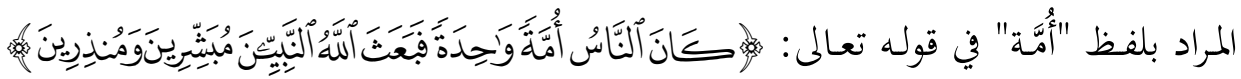
(البقرة: 213) هو الدِّين؛ فالناس في بداية أمرهم كانوا على دِين واحد يجمعهُم، ومكثنوا

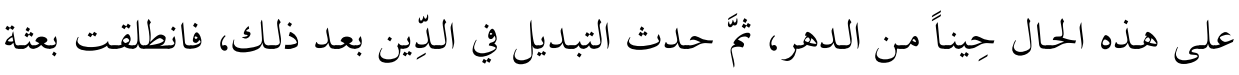

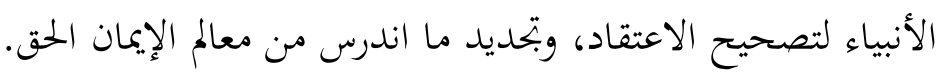
8 8. رجل جامع لحخصال الحخير، وقائم مقام جماعة في عبادة الله:

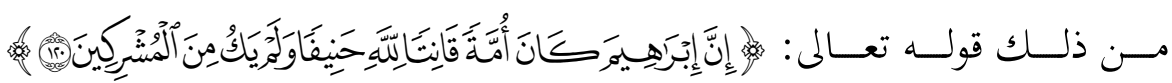

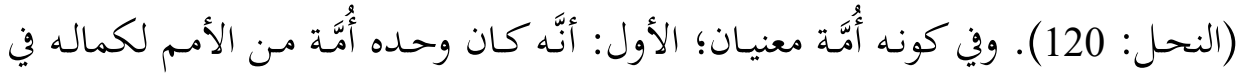

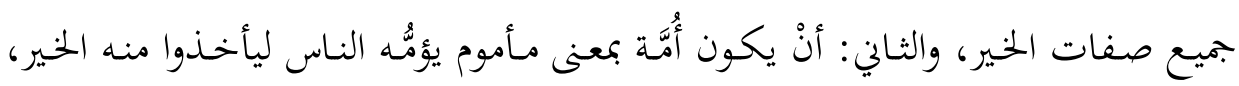

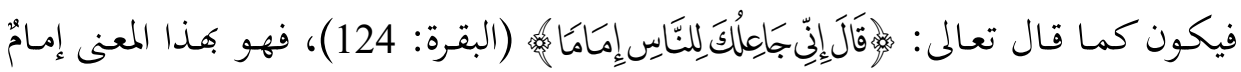

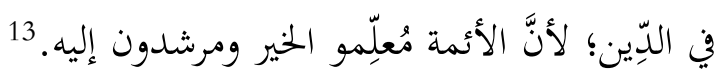

\section{9. جماعة المسلمين المُوحَّدة الجُتمعة على الحقى:}

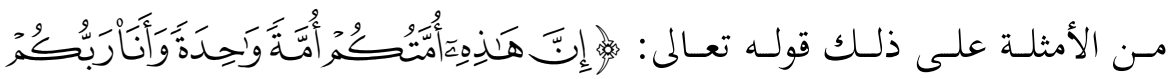

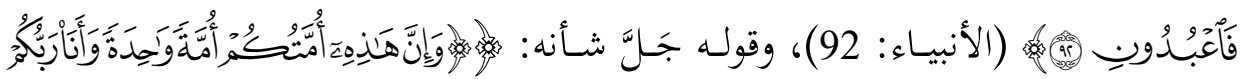

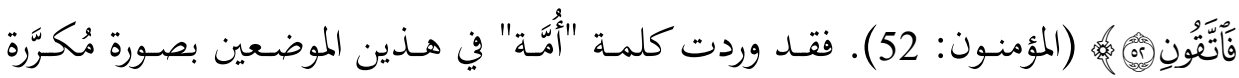

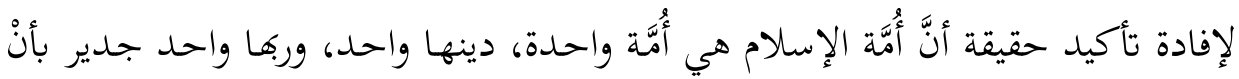

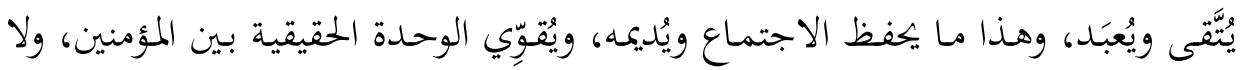
يُمكِنِ لشيء سواه أنْ ينوب منابه في ذلك الأمر، وسيأتي تفصيلٌ أكثر في هذا بعدُ. 13 الزخشري، جار الله أبو القاسم محمود بن عمر. تفسير الكثاف، بيروت: دار الكتاب العربي، ط1، 1407هـ، ج2، الكن،

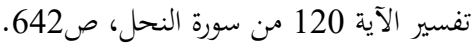




\section{0. جامعة الروابط الأسرية والقرابات النَّسبية التراتبية:}

للأُمَّة في النسق القرآني أنساق تعود بالفرع إلى أصله الأول، وقد أظهر الكتاب المبين

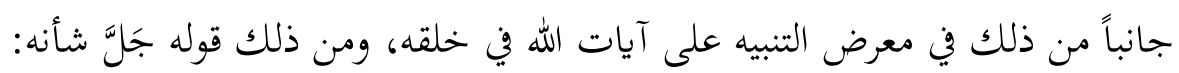
-

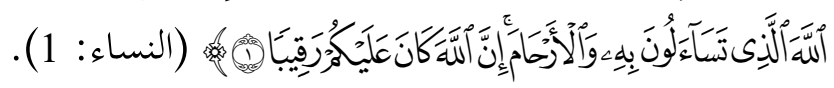

-

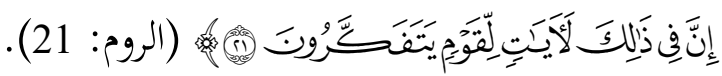
-

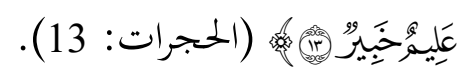

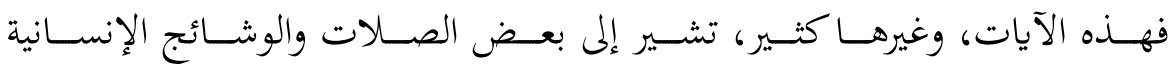

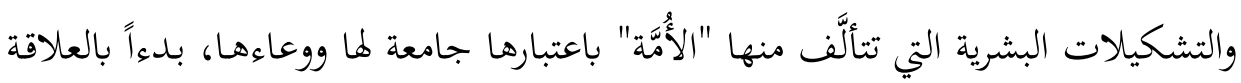

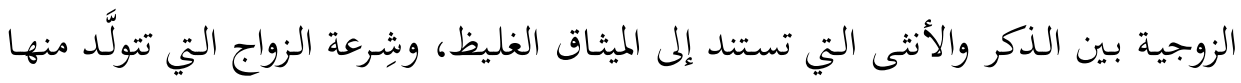

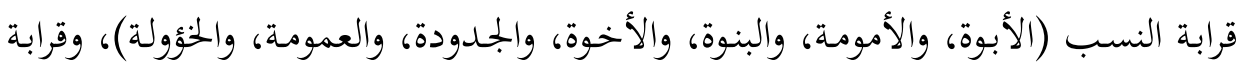

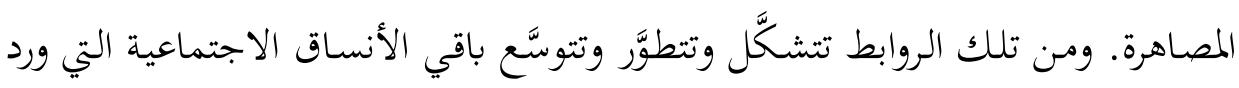

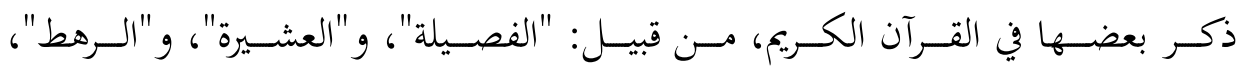

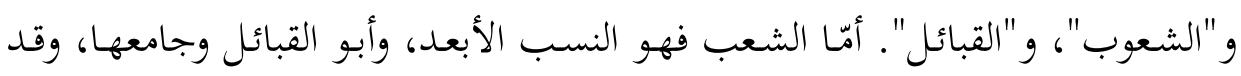

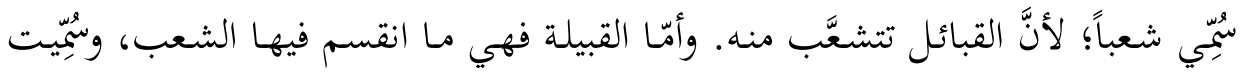

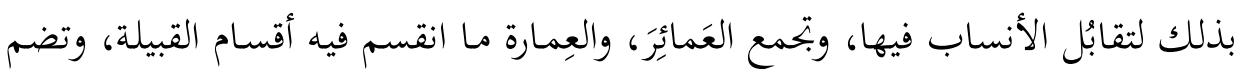

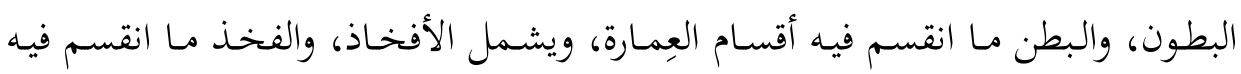


أقسام البطن ويجمع الفصائل، والفصيلة عشيرة الرجل ورهطه الأَّْنَون وأقرب آبائه إليه. 14

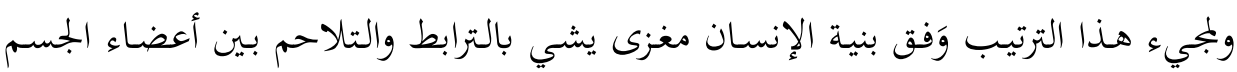

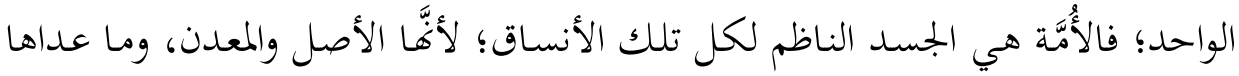
كالجداول المتشعبة منها.

إنَّ إقرار القرآن الكريم بانتظام البشر بالفطرة ضمن أُسر وقبائل وشعوب، واعتبار

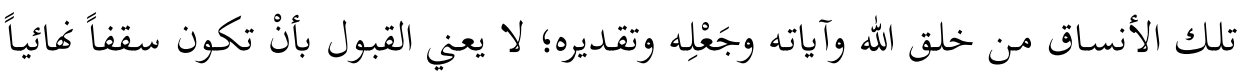

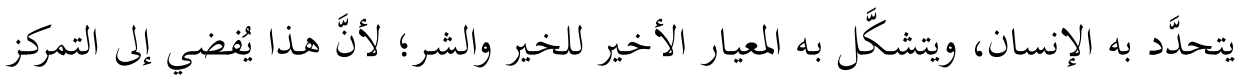

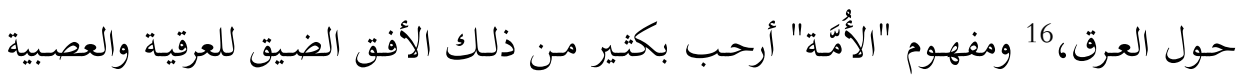
القومية وما يجري مجراهما.

هذا طرف من دلالة "الأُمَّة" بصورة عامة في النص القرآني، يُظهِر المعنى المتفرِّد الذي تنطوي عليه، ويكشف اتسـاع هـا المفهوم وشثموله جملة مـن الحقـائق تصوغ في كليتها

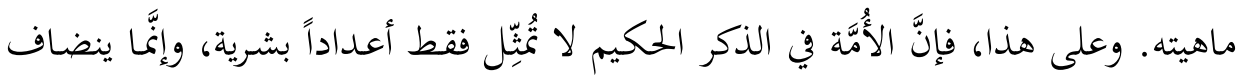
إليها معانٍ وقيم ذات مضمون إيماني وأخلاقي، وفعل عمراني قائم على تفاعل واعِ بين

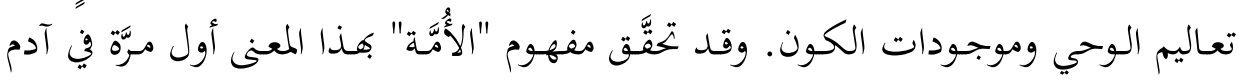

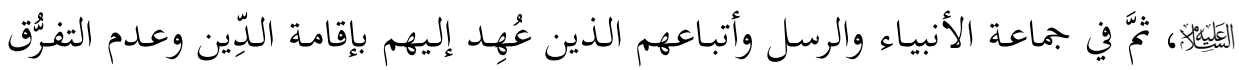

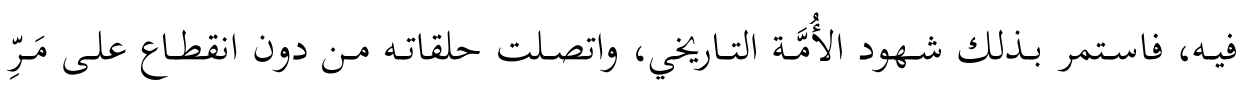

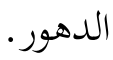

ومسن البصـائر التي يُعـدِّهـا القـرآن الكريم في هـذا الشـأن تسـاوي الأمـم جميعهـا مـن

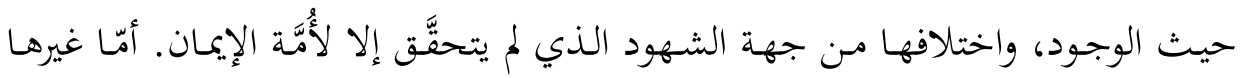

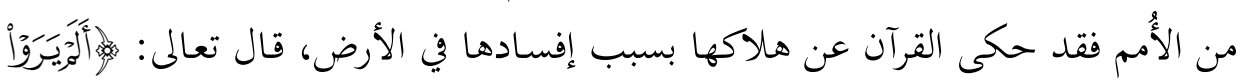
14 القلقشندي، أبو العباس أحمد بن علي بن أممد الفزاري. فهاية الأرب في معرفة أنساب العرب، تحقيق: إبراهيم

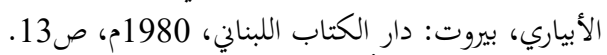

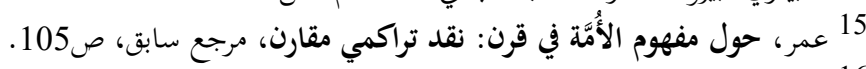

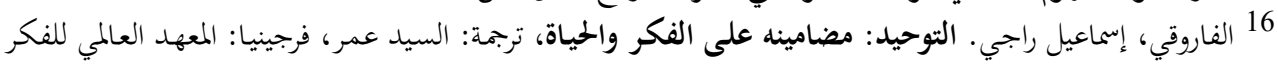
الإسلامي، 2016م، ص184. 


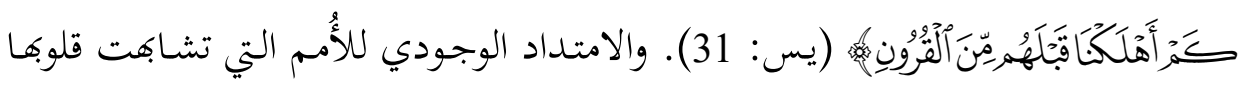

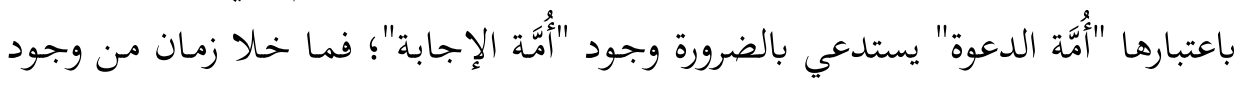

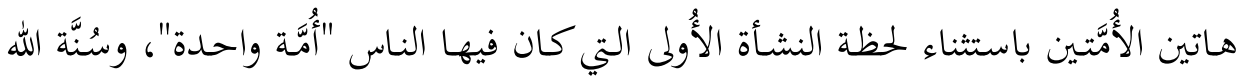

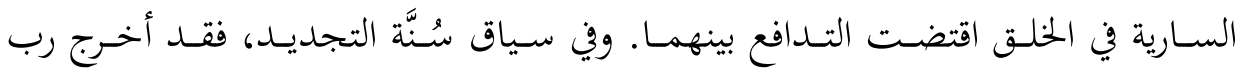

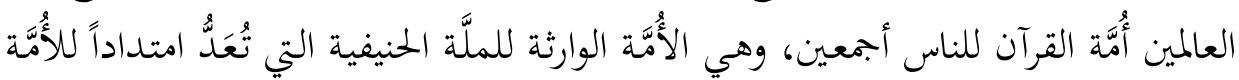

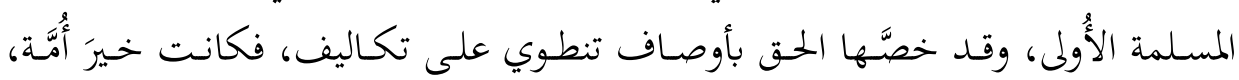

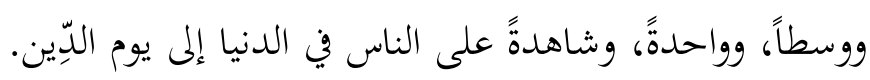

\section{ثاثاً: الأوصاف المقترنة بالأُمَّة في القرآن الكريم}

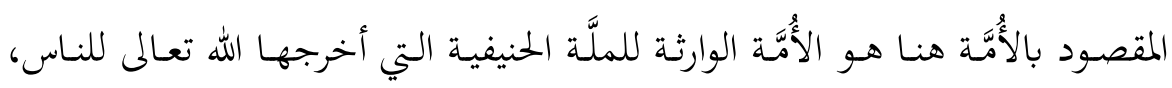

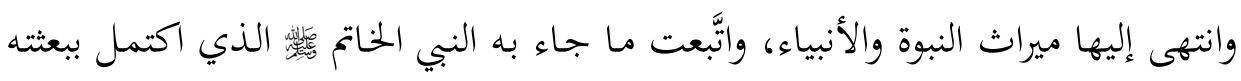

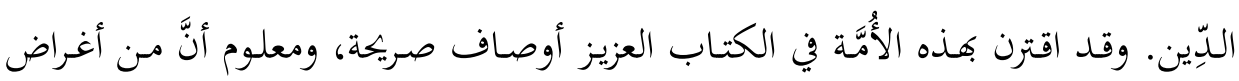

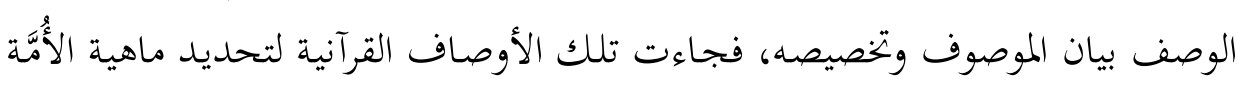

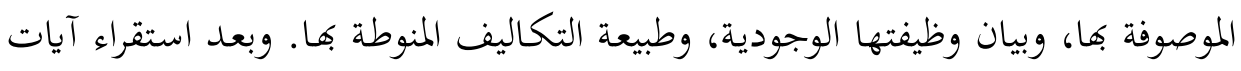

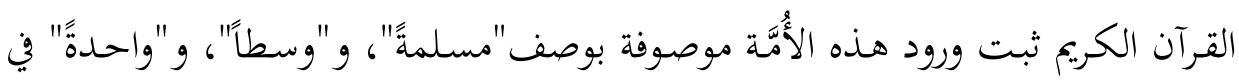

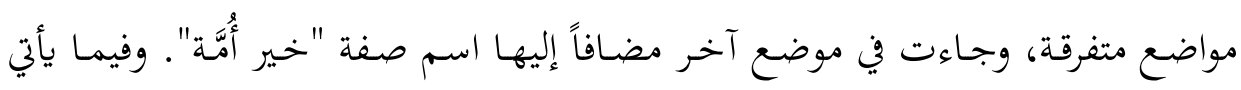
بيان لمضمون كل وصف على حِدَة:

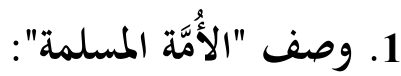

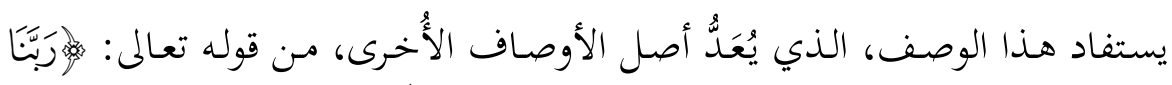

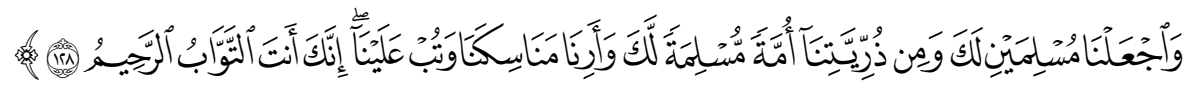

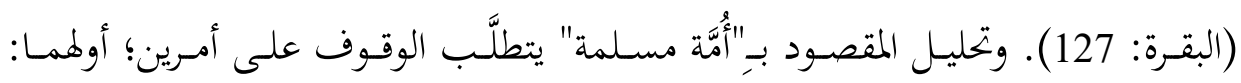

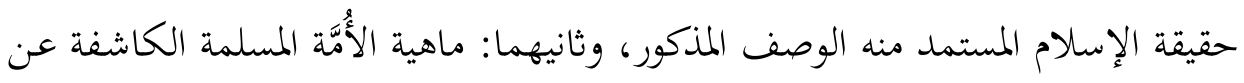
شروط انطباق الوصف على الموصوف. 
أ. حقيقة الإسلام: يدور لفظ "الإسلام" على الاستسلام والانقياد. يقال: أَسْلَمَ بمعنى دخل في السلم، وهو الاستسلام، واستسلم؛ أي انقاد وصار مُسلِماً، وأَسلَم أمره إلى الله؛ أي سلم. وأسلم من الإسلام، وهو الانقياد؛ لأنَّهَ يَسْمَم من الإباء والامتناع. 17 وقد صار لهذه الكلمة في القرآن الكريم معنئ خاصه، هو طاعة الله، مثل لفظ "الدّيّين" الذي يعني في أصله اللغوي الطاعة، وقد استعمله العرب لطاعة الله تعالى. ولفذا المعنى

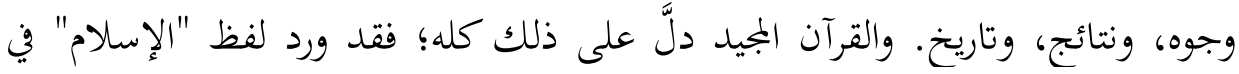
الكتاب المبين بمعنى العبودية؛ أي تسليم النفس لرضا الله تعالى بالكلية، والاستجابة

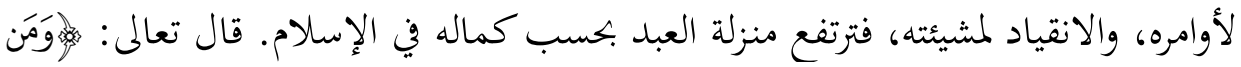

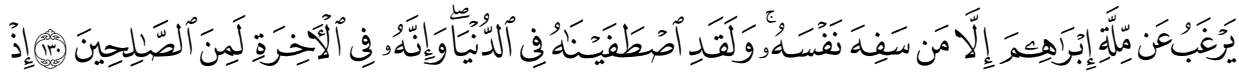

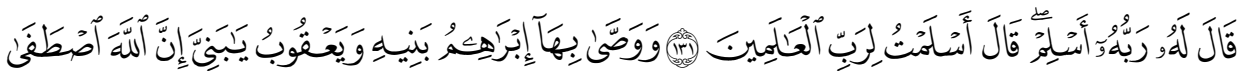

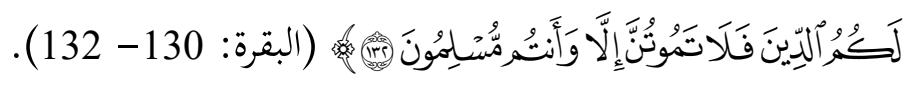

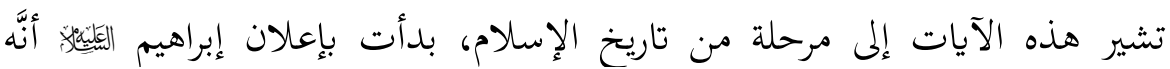

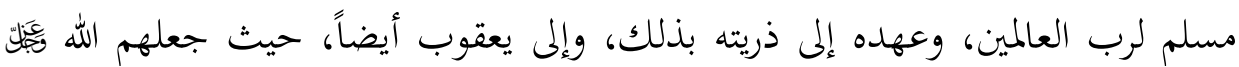

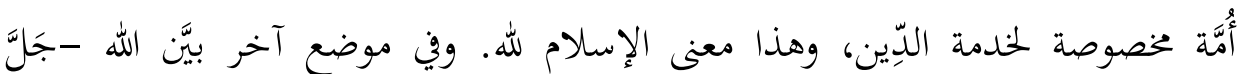

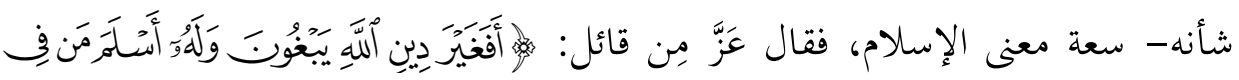

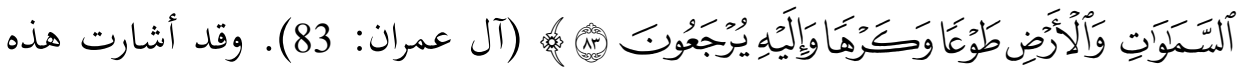

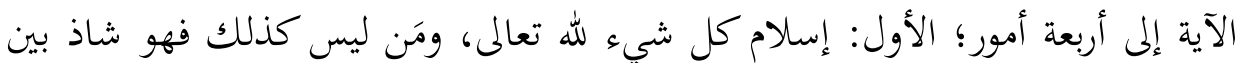

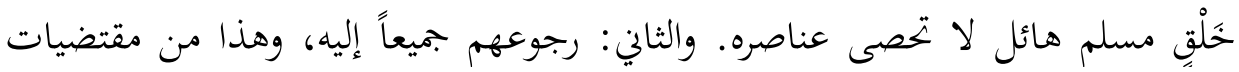

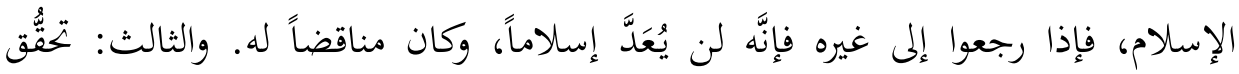

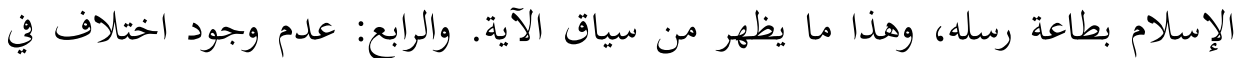

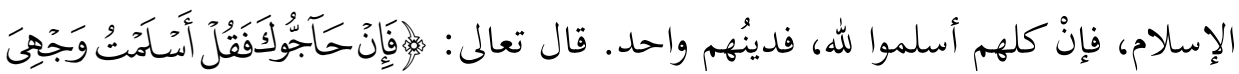

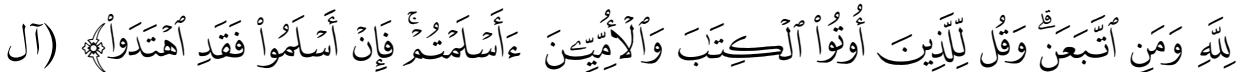
عمران:20)؛ ذلك أنَّ الإسلام ينافي الشرك، فلمسلم مؤمن بالله الواحد الأحد، وهذا

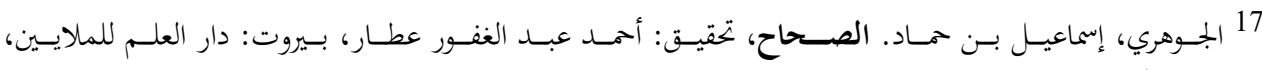


مقتضى إسلام الوجه الله، ومَن أسلم فكأنَّه عاهد الخالق بالطاعة، 18 ولذلك قال تعالى:

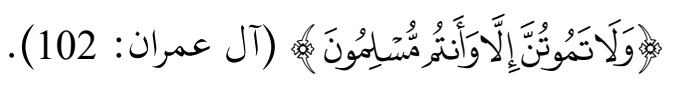

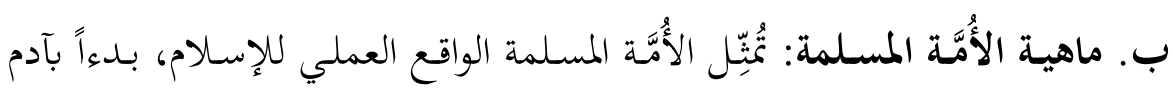

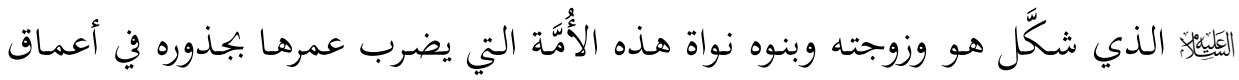

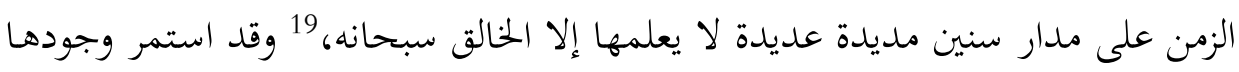

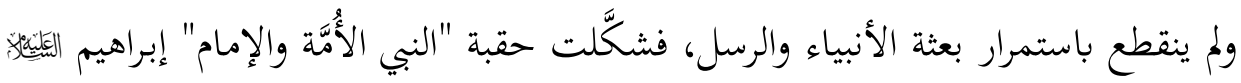

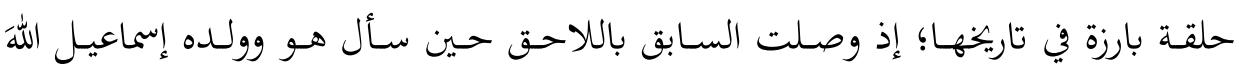

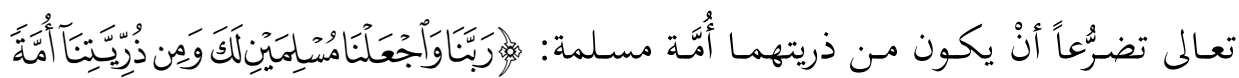

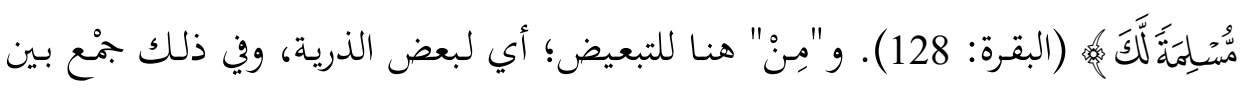

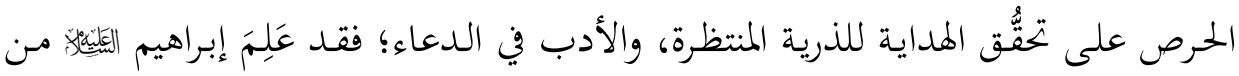

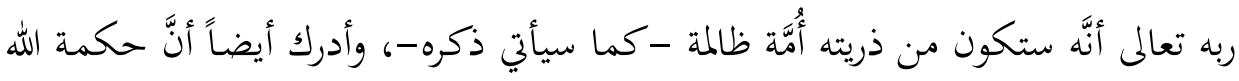

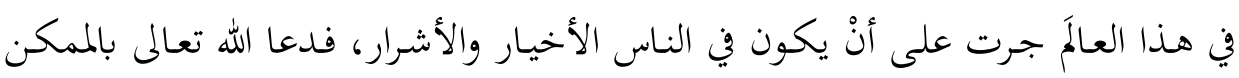
عـادة.20 وقد جـاء هـا الدعاء في سياق حافل بالـدلالات، أظهرهـا الإشـارة إلى ابتلاء

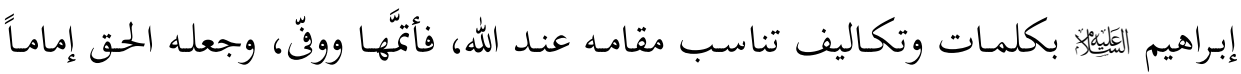

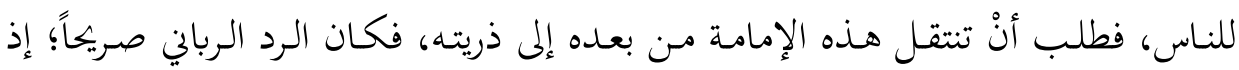

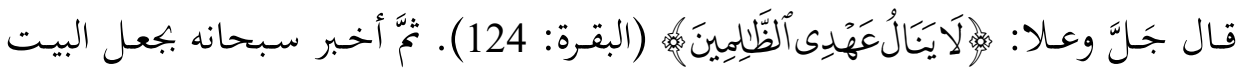

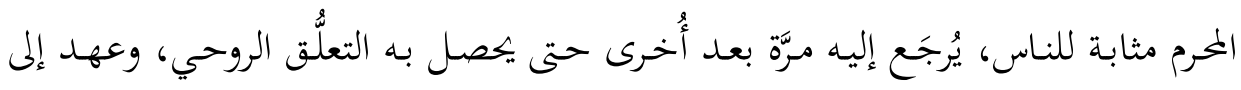

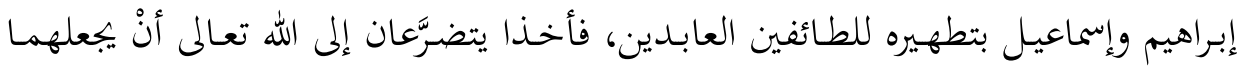

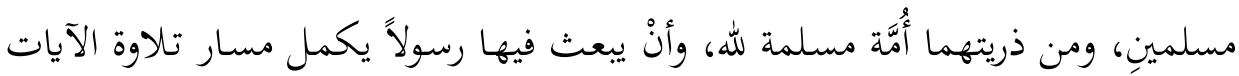
والتزكية والهداية، فكانت الاستجابة الإلهية، وصار الدعاء حقيقة حين أسلمت جُملُّ قبائل 18 الفراهي، عبد الحميد. مفردات القرآن: نظرات جديدة في تفسير ألفاظ قرآنية، تحقيق: محمد أجمل أيوب، بيروت:

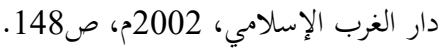

$$
\begin{aligned}
& 19 \text { انظر تفصيل ذلك في: }
\end{aligned}
$$

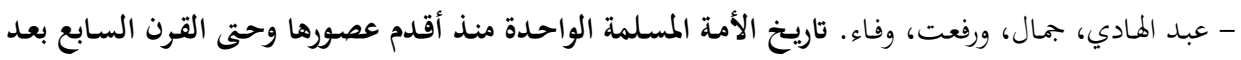

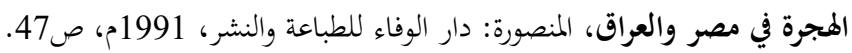

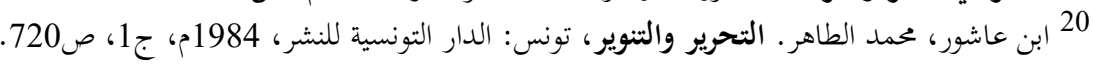




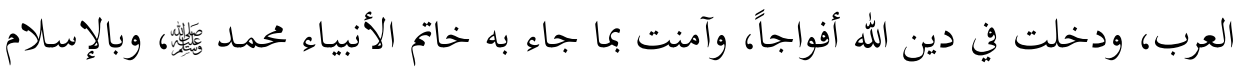

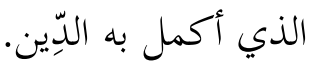

وقد خاطب الحق الأُمَّة المسلمة الوارثة للملَّة الحنيفية التي صُنِعت آنذاك على عين

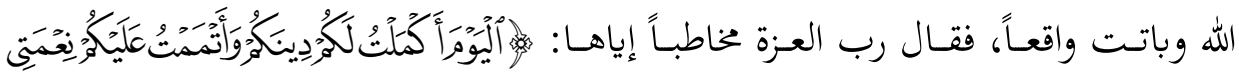

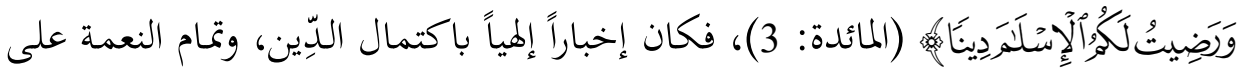

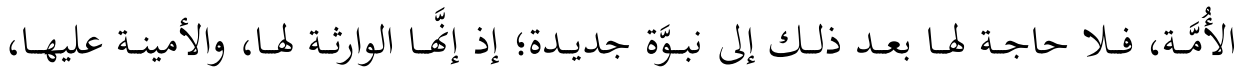

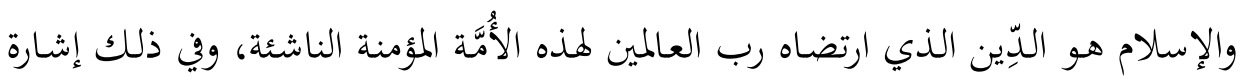

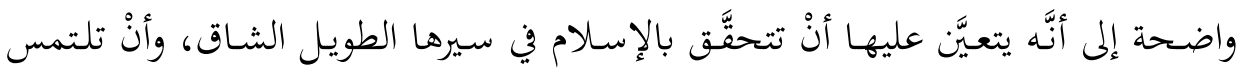

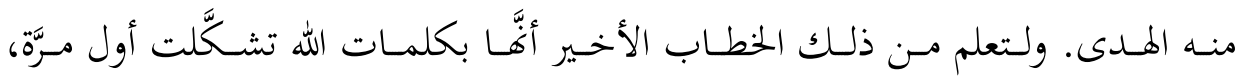

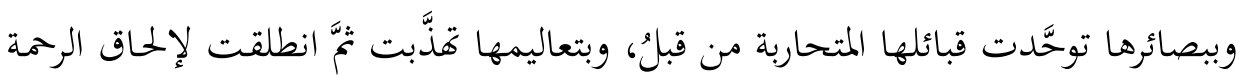

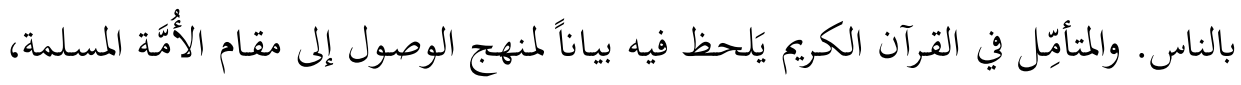

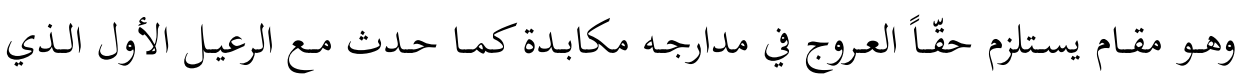

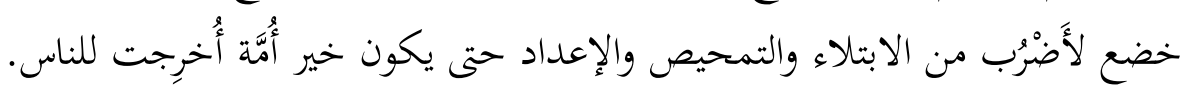
ومـن كحلام الله تعالى تُستفاد هوية الأُمَّة المسلمة باعتبارهـا تكليفـاً، فهي ابتـداءً أُمَّة

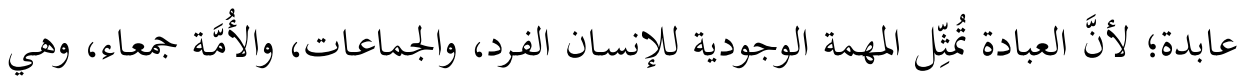
مـن مستلزمات الاستخلاف في الأرض، وبتسيد لحقيقة الطاعـة الصادقة والانقياد التام للحـق جَـلَّ شـأنه، ووَصْـل الروح بعـالَّم الغيـب، وإسـلام الوجـه للبـارئ في صـوره الفرديـة

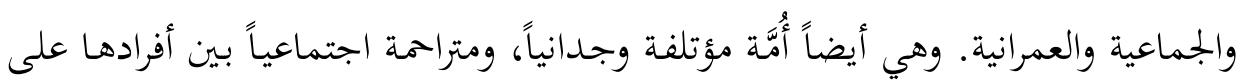

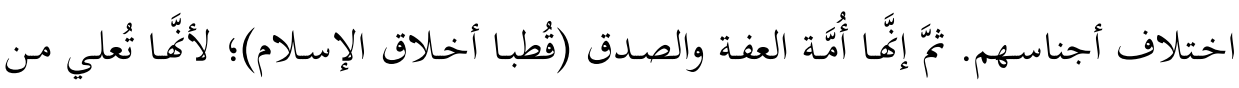
شأن الفضيلة، وتغرس القيم، وتتعهَّدها، وتحرسها من الضياع بمبدأ الأمر بالمعروف والنهي إلها عن المنكر، وذلك مسلكها للتحصين من التسفُّل الأخلاقي، وشرط لبقائها على الحيرية.

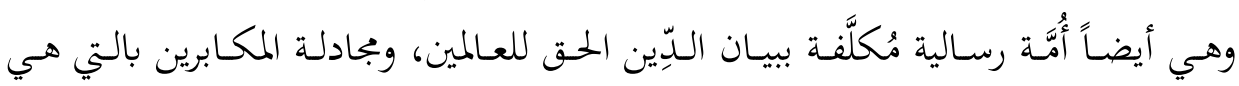
أحسن؛ إحقاقاً للحق، ودحضاً للباطل، ودفعاً للأوهام التي أضلَّت خلقاً كثيراً. 


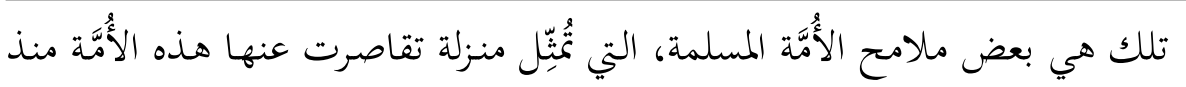

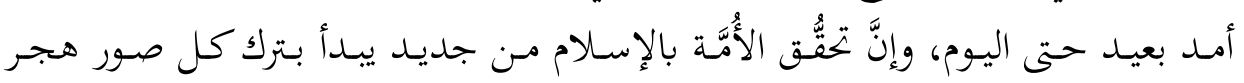

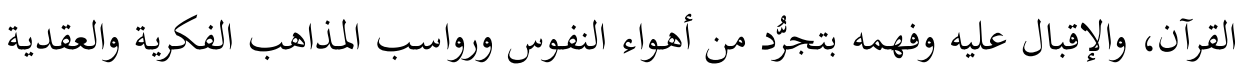

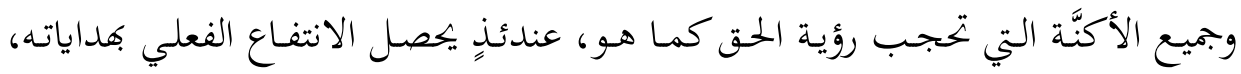
فيقع التحوُّل المأمول في النفس والفكر والسلوك. ولا شكُّ في أنَّ التجربة النبوية تُمُّبّل خير

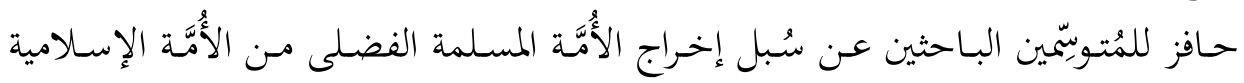
الحالية.

\section{2. وصف "الأُمَّة الوسط":}

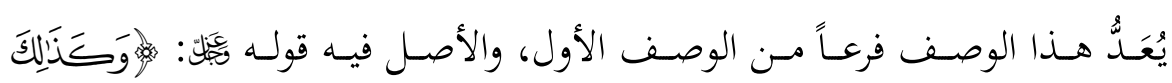

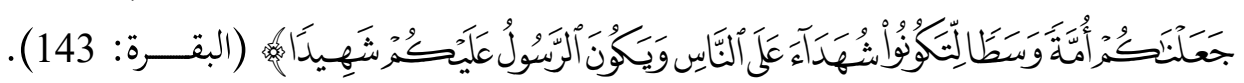

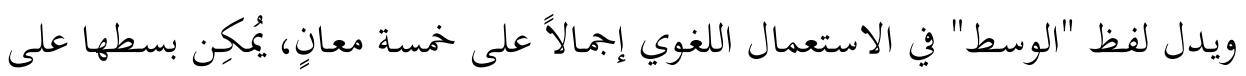

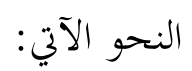

الأول: البَيْنِية؛ أي الوجود بين أشياء أو أشخاص.

$$
\text { الثاني: الوقوع في وسط الشيء. }
$$

الثالث: الأجود والأفضل بالقياس إلى غيره.

الرابع: ما قام في النفس أنَّه مستقيم؛ وهو العدل والإنصاف في الأمور كلها.

$$
\text { الخامس: القصد المصون عن الإفراط والتفريط. }
$$

ومدار هذه الدلالات نفسها يقوم على أصلينِ جامعينِ؛ الأول: مركز الشيء وبؤرته،

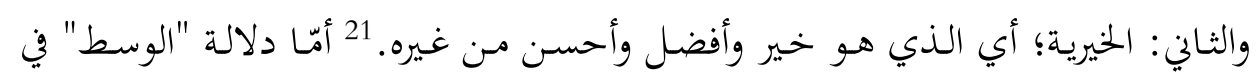
القرآن الكريم فيُمكِن بيانا فيما يأتي:

$$
\begin{aligned}
& 21
\end{aligned}
$$

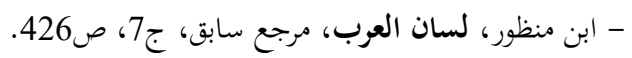

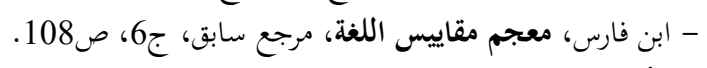

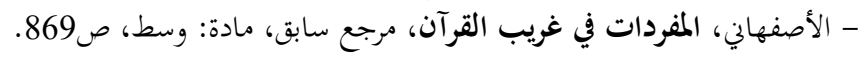




\section{أ. لفظ "الوسط" في القرآن الكريم:}

وردت مادة "وسط" في الكتاب العزيز بصيغ مختلفة في خمسة مواضع، 22 هي:

شَهِيدَا مُهُ (البقرة: 143)؛ فقد جاءت لفظة "وسطاً" بمعنى "خياراً"، وسيأتي تفسيرها لاحقاً.

الوسطى بينها، أو الفضلى منها خصوصاً. 23 -

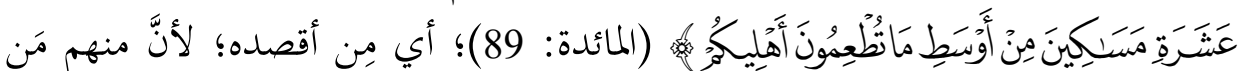
يُسرِفِ في إطعام أهله، ومنهم مَن يقتر . 24

يُستفاد ميّا سبق أنَّ لفظ "الوسط" في القرآن الكريم جاء بمعانٍ لا تبتعد في عمومها عن دلالاته اللغوية؛ فباستثناء الآية الأخيرة التي يفيد فيها معنى الوقوع وسط المكان أوسان أوسان الجمع، فإنَّه لم يخرج في باقي الآيات عن مدلول الخيرية والقصد والاعتدال.

والمُلاحَظ أنَّهَ حين يُستعمَل في سياق قرآني مُحسَّد، فإنَّه يأتي في بعض الآيات مُحمَّلاً

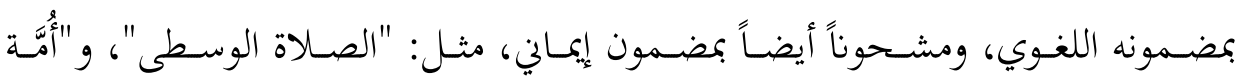

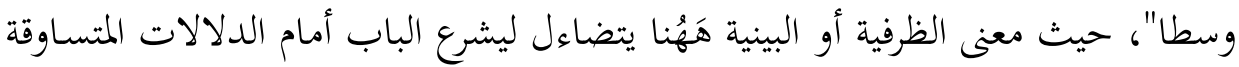
مع سياق حافل بالحقائق، فيرتقي اللفظ من المعهود في الكلام البشري إلى مقام التعبير

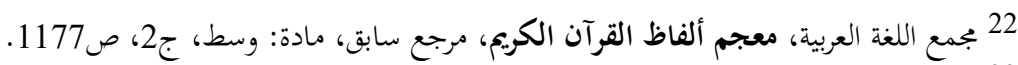

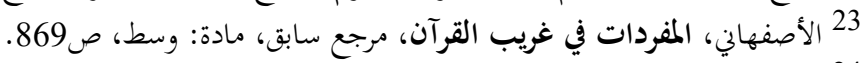

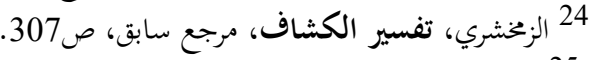

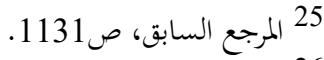

$$
\begin{aligned}
& 26 \text { الطبري، جامع البيان في تفسير آي القرآن، مرجع سابق، ج3، ص522. }
\end{aligned}
$$


عن بِينـات الذكر الحكيم، ثمَّ يصبح للمفهـوم أبعاد أخُرى، وهـو مـا سيأتي تفصيله تالياً

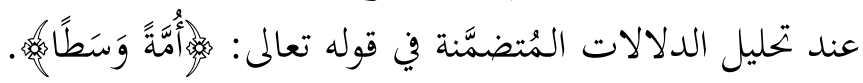

\section{ب. مضمون الأُمَّة الوسط:}

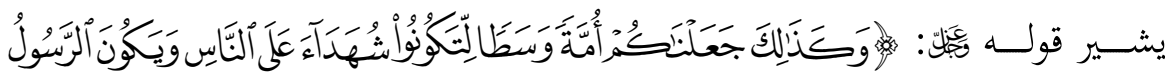

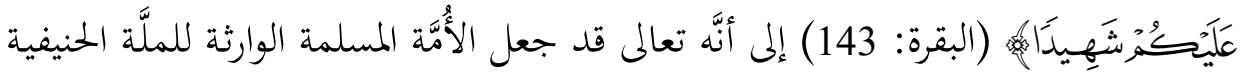

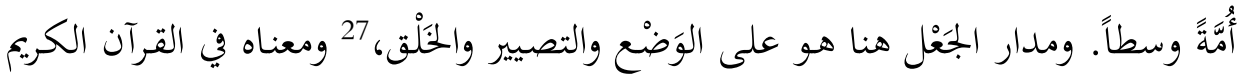
يأتي على خمسة أوجه، هي: الوصف، والفعل، والقول، والخَلْق، والتسمية. 28

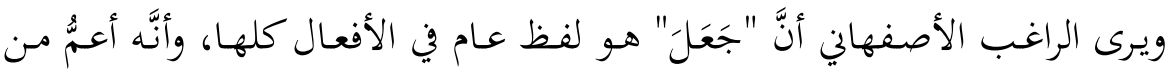

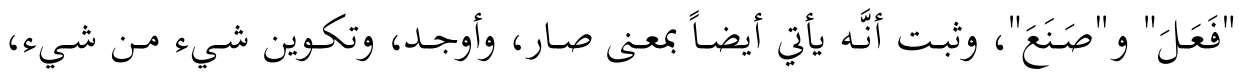

وتصيير الأمر على حالة دون حالة، والحكم بالشيء على الشيء، حقّاً كان أو باطلاً. 29

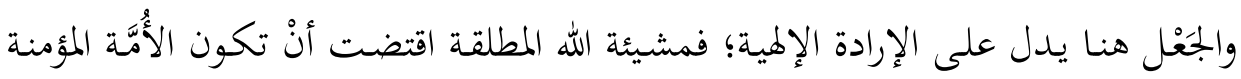
"وسطاً"، وفي ذلك حكمة ربانيـة بالغة، يمُكِن استكناه بعض مظاهرهـا مـن خلال تتبُّع سياق هذا الجَعْل المرتبط بجَعْل آخر يخص القِبلة وابتلاء الأُمَّة الوارثة لملَّة إبراهيم بترك قِبلته والابجـاه جهة المسجد الأقصى، فكان التمحيص ليَعلمَ الله -وهو تعالى أعلم - مَن يتَّع

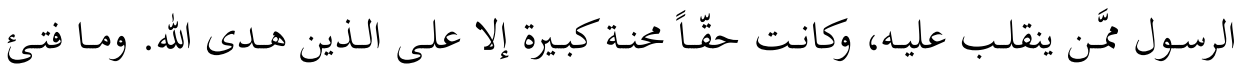

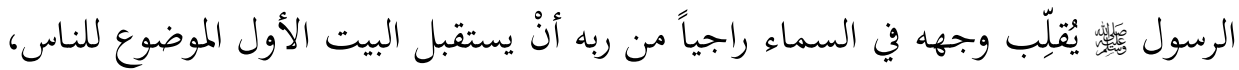
الذي جعله الحق مباركاً وهدىً للعالمين، فتحقَّق التحويل إلى القِبلة المرضية، وارتقت الأمَّة

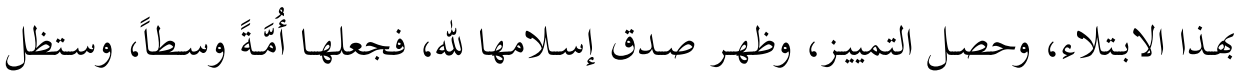
كذلك ما لمُ تِيْْ عن الصراط المستقيم. وبيجدر بنا في هذا الموضع أنْ نقف على بعض ما

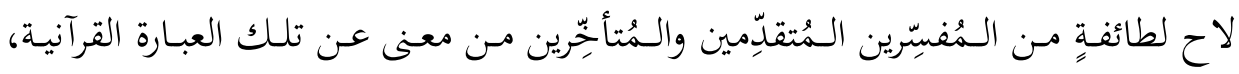
وكيف تطوَّر مفهومها عندهم؛ إسهاماً منّا في جمع أظهر الدلالات المستنبطة، وسعياً إلى

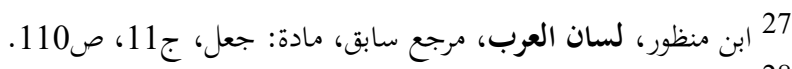

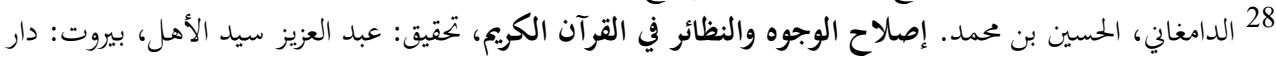

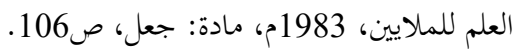
29 الأصفهاني، المفردات في غريب القرآن، مرجع سابق، مادة: جعل، صادة ص94. 


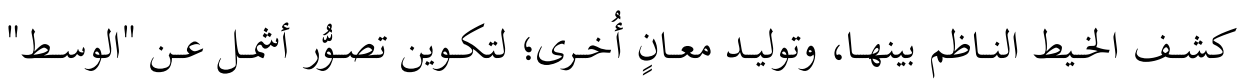

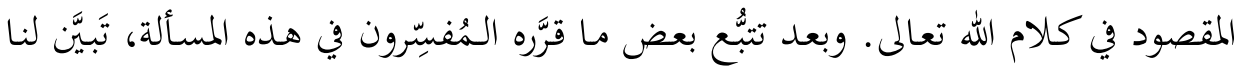
ما يأني:

\section{- الأُمَّة الوسط أُمَّة الاعتدال في اللِّين والتدين:}

أشـار إلى هـذا المعنى العديـد مـن الـمُفسِّرين، مثل ابـن جريـر؛ إذ قال: "وأنا أرى أنَّ (الوسط) في هذا الموضع هو الوسط الذي بمعنى الجزء الذي هو بين الطرفين، مثل وسط

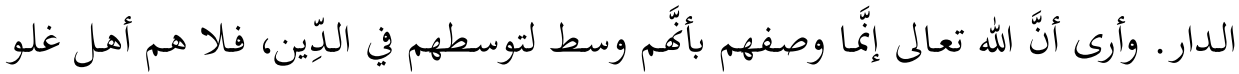
فيه غلو النصارى الذين غلوا بالترهب، وقولهم في عيسى ما قالوا فيه، ولا هم أهل تقصير

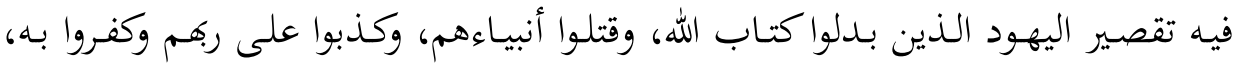

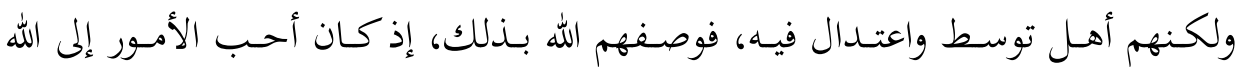
أوسطها.

إذن هـي أُمَّـة معتدلة قياسـاً إلى غيرهـا مـن الأُمـم التي انحرفـت عـن سـواء السـبيل، وبتحاوزت حدود التوسط في أمور الدّيّن والدنيا. وبالموازنة مع النماذج البشرية المذكورة في

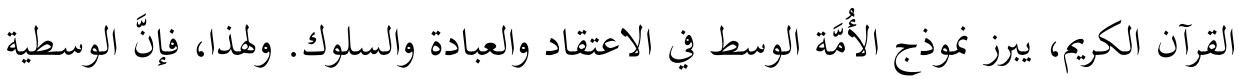
تدل -بدايةً- على الاعتدال بوصفه خصيصةً، ومنهجاً، ومقصداً، ومقياساً يميز المنظومة

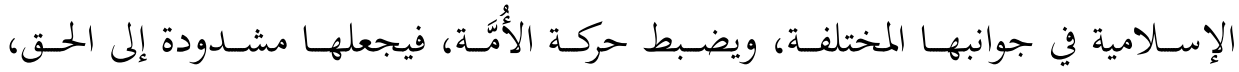
ومسترشدة به في النهوض بأعباء التكليف ومقتضيات الاستخلاف.

\section{- الأُمَّة الوسط صاحبة الؤية الكلية:}

من الإشارات النفيسة في هذا السياق ما ذكره البقاعي في تأويل الآية؛ إذ قال: "وملا

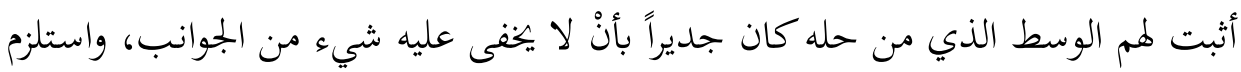

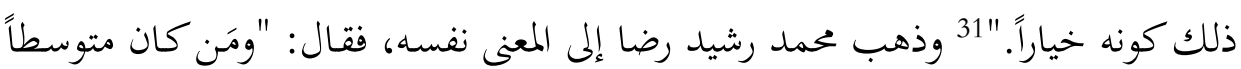

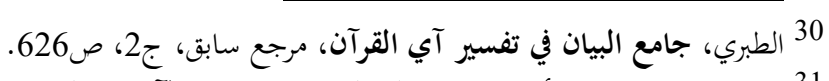

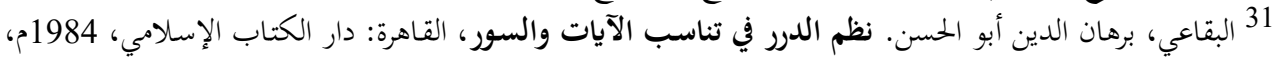




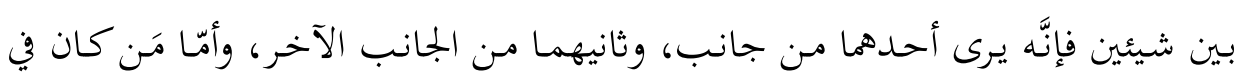

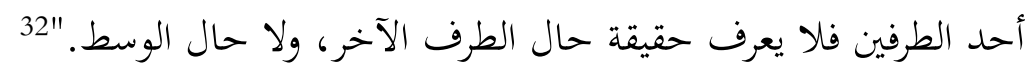

إنَّ هذه المكانة التي اختصت بها الأُمَّة تمنحها القدرة على النظرة الكونية والحضارية

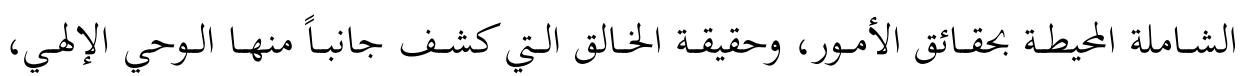

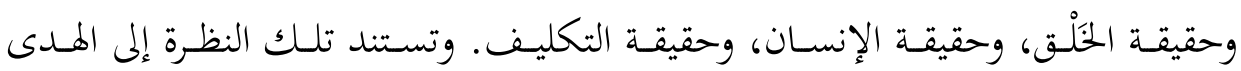

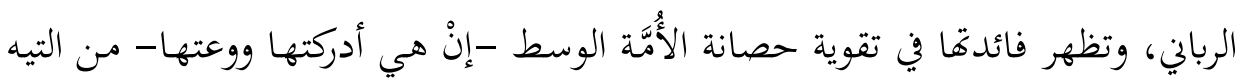
في سـاحة الوجـود، ووضع إنجازهـا الحضـاري موضع الرشـد، ومصـداق ذلك هـو التـاريخ

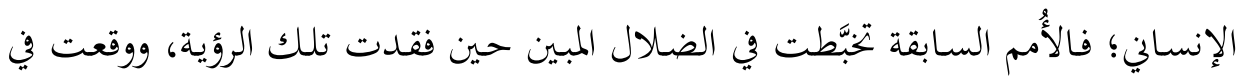

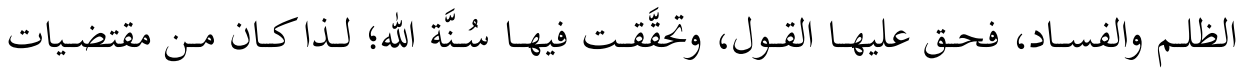

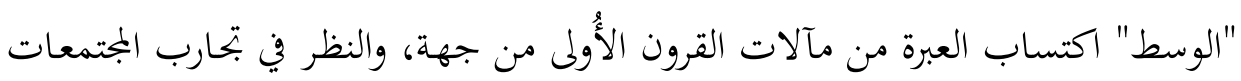

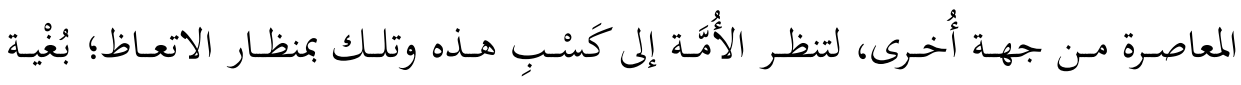
استتباط سـنن النهوض والسقوط التي تتيح امتلاك الرؤيـة الواضحة الهادية إلى السـمو الإيماني والترقي المادي المشدود إلى قيم الدِّين الحق.

\section{- الأُمَّة الوسط ذات شريعة واضحة ميسرة:}

قال الطاهر بن عاشور في هذا السياق: "والآية ثناء على المسلمين بأنَّ الله قد ادخر

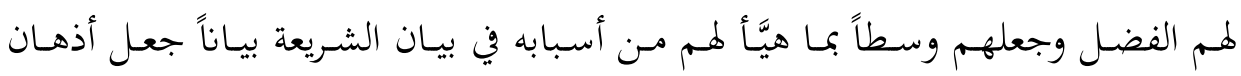

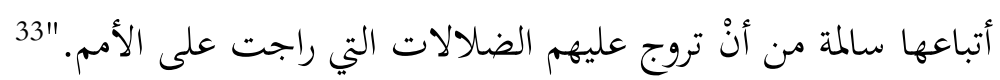
وثمَّة تلازم بين وسطية الشريعة ووسطية الأمُّةَ، يظهر في طبيعة هذه الثِّرعة الربانية الخاتمة، التي تنطوي على توجيهات عدَّة، والتي يراد بها ابتداءً تزكية النفوس، وبناء الأُمَّة

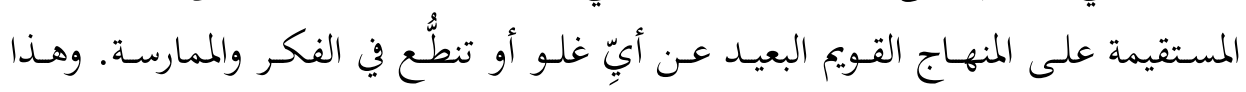

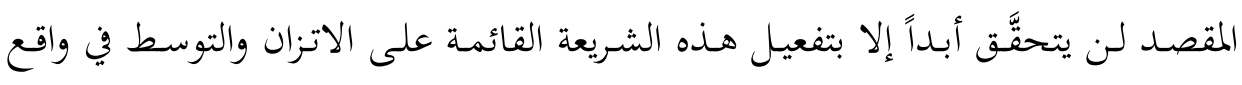

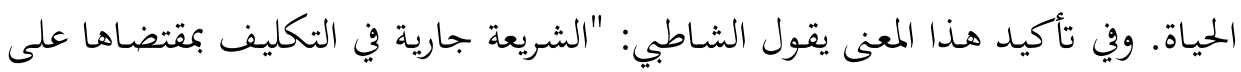

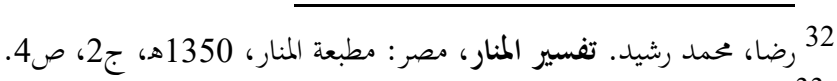

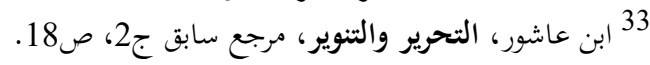


الطريق الوسط الأعدل الآخذ من الطرفين بقسط لا ميل فيه، الداخل تحت كسب العبد

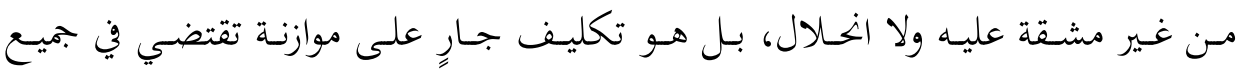

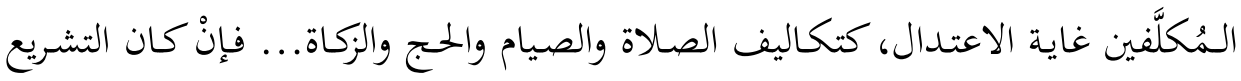

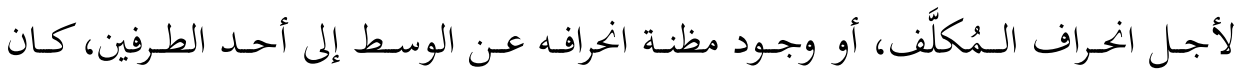

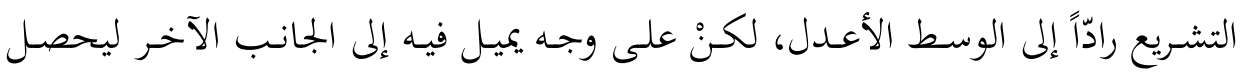

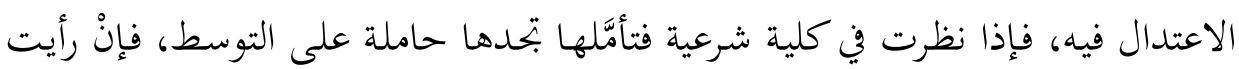

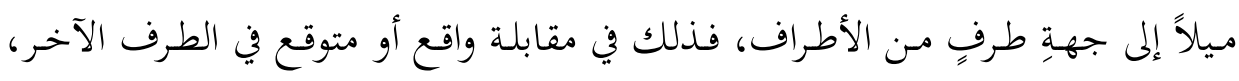

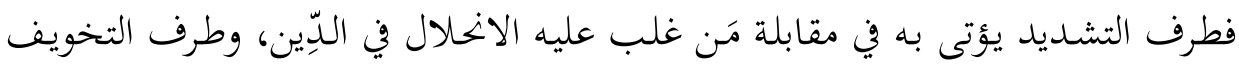

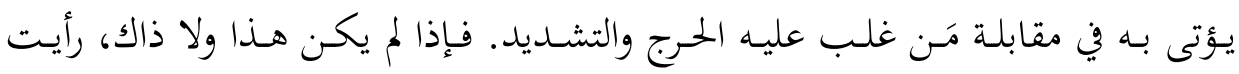

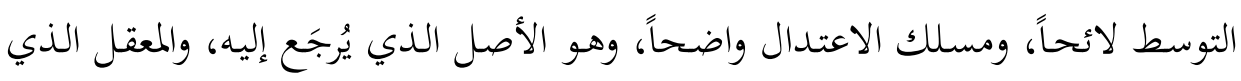
يُلجَأ إليه."

\section{- الأُمَّة الوسط منهاج حياة قويم:}

يرى سيد قطب -في معرض تحليله الآية نفسها- أنَّ هذه الأُمَّة وسط؛ أي قائمة

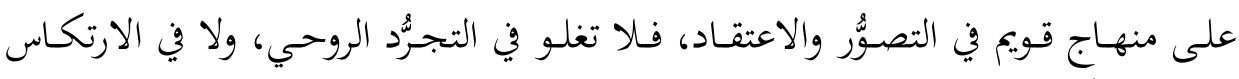

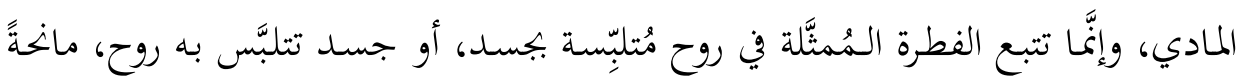

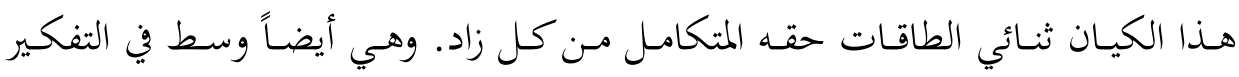

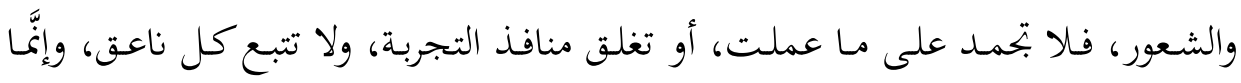

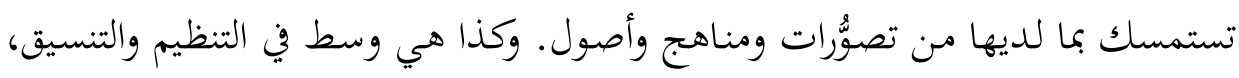

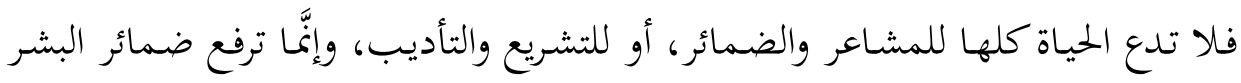

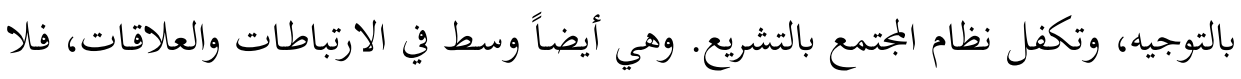

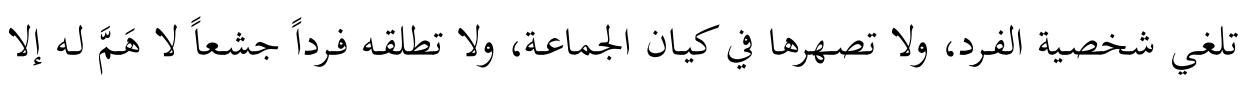

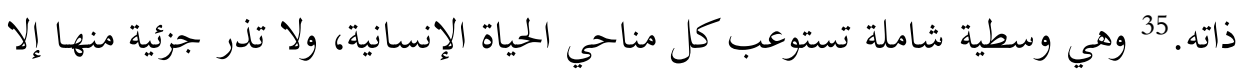
أخضعتها للقسطاس المستقيم، في وفاق تام بين نواميس الكون وسننه الموضوعة في البدء

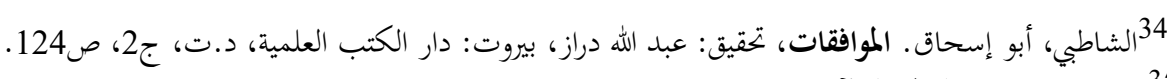

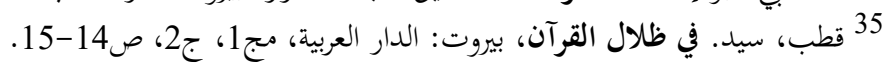




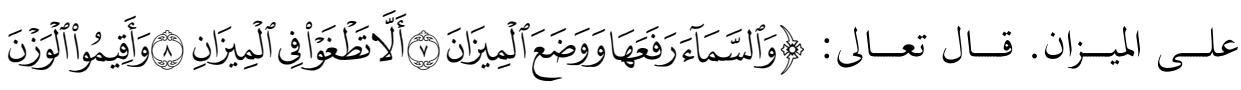

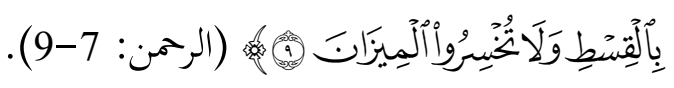

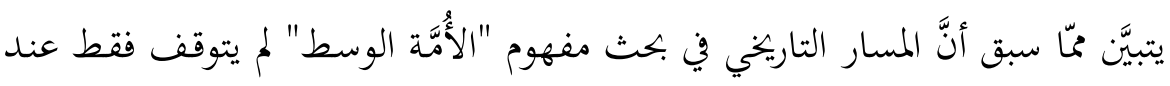

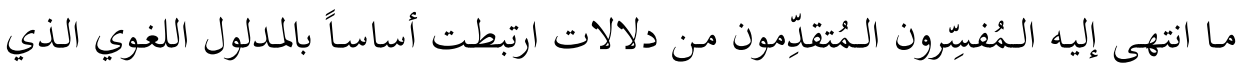

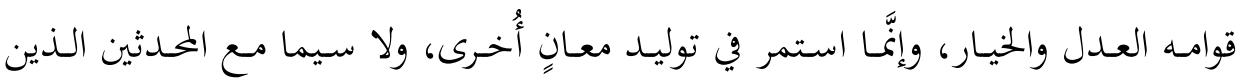

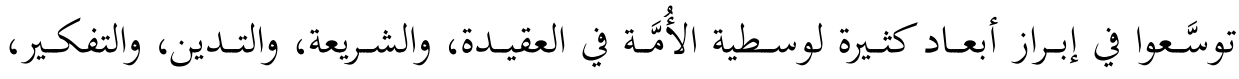

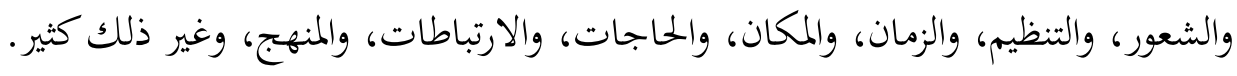

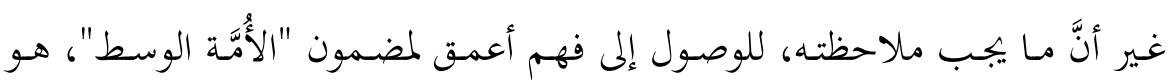

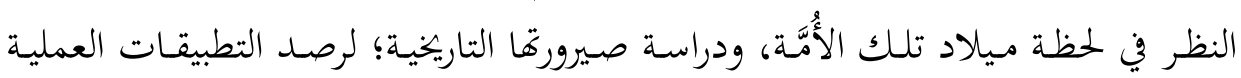

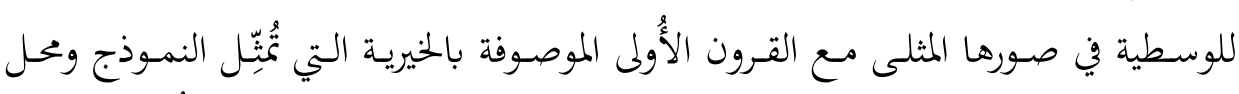

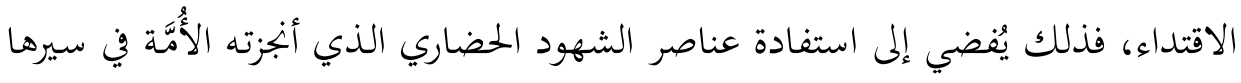
الأول المُسدَّد بالوحي.

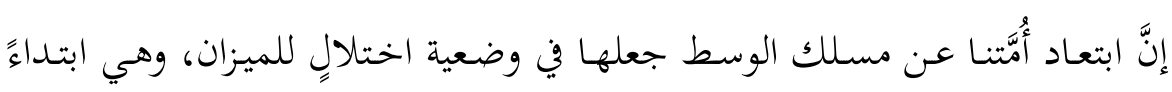

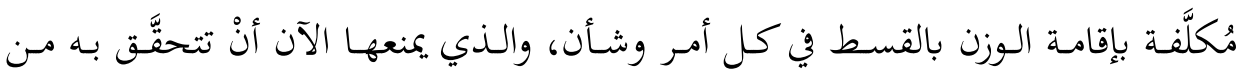

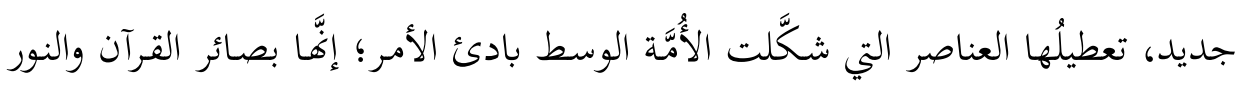

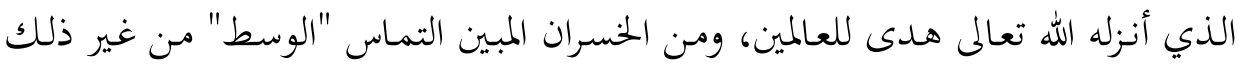

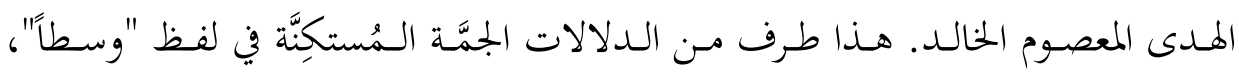
وسنمضي الآن في استكشاف الوصف الذي يليد.

\section{3صف "الأُمَّة الواحدة":}

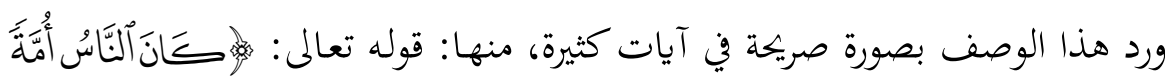

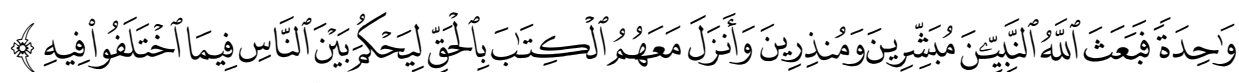

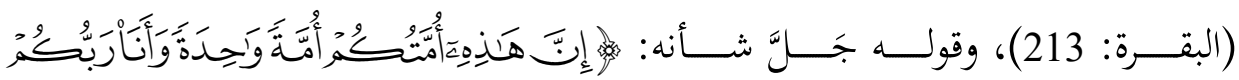

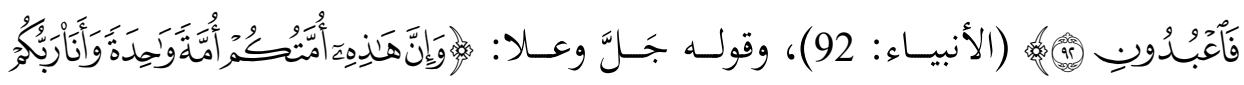

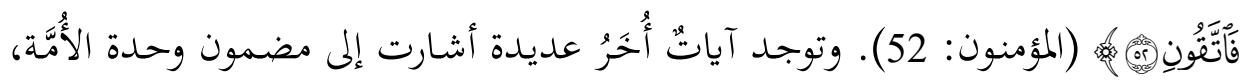


بدعوتا إلى الاعتصام بحبل الله، والائتلاف، والأخوة، والموالاة بين المؤمنين، وتحذيرها من الفُرقة والاختلاف.

إذن، فالأُمَّة هي الجماعة الموحدة على مقصد واحد. وقد فسَّر أكثر المُففسّرين لفظ

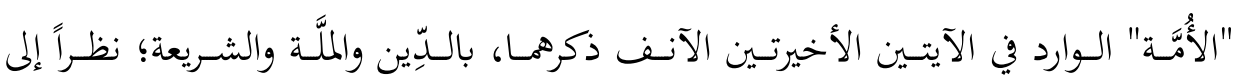
الاجتماع على مقصد واحد، و تأكيد توحيد الوجهة نحو الله الواحد الأحد. ومتى تحقَّق الاجتماع والاتحاد على هذا القصد، حصل الائتلاف بين المؤمنين الموحدين المخلصين

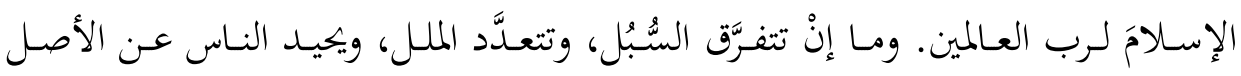

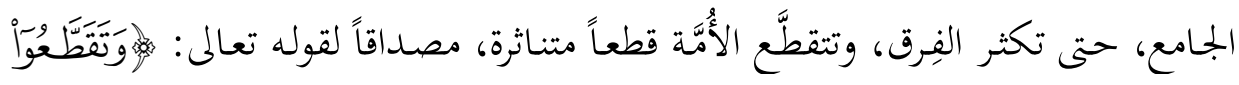

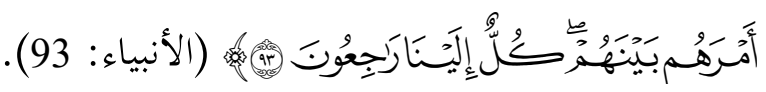
إنَّ الدِّين الحق هو العنصر الرئيس لوحدة الأُمَّة المسلمة، والأساس الذي يقوم عليه

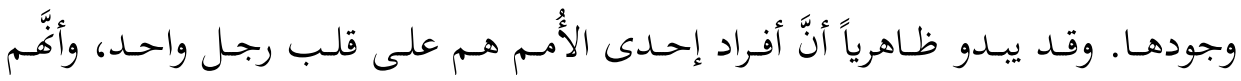

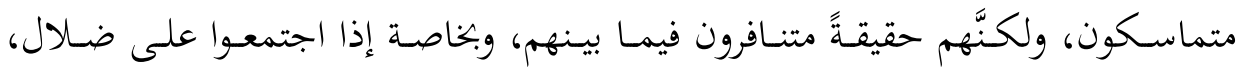
وانعـدم الأصـل الحقيقي الجـامع بـين القلوب، الـذي يـربط بينها بإحكـام. قـال تعـالى:

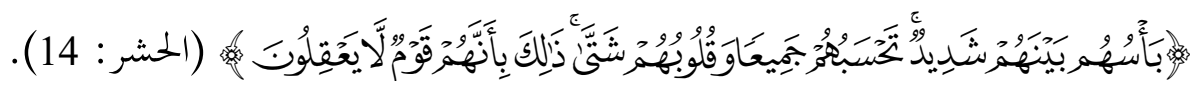
لقد كشف العليم بذات الصدور حقيقةً، ربَّا كانت غائبة قبل هذا الإخبار عن النبي

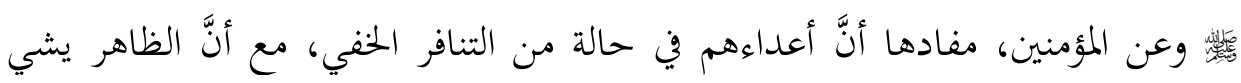
بوحدة الصف. والمعنى المستفاد من ذلك هو أنَّ القوم الذين قصدهم الله تعالى غير الهي مجتمعين على شيء ذي شأن يوقعهم في موقع المهابة منهم؛ إنَّهم متضادون مختلفون اختلافاً كبيراً، وهذا مكمن ضعفهم. فالاجتماع على المصالح الدنيوية هو اجتماع واهن، شبيه بالوهن في بيت العنكبوت، بحيث يتبلَّد بذهاب تلك المنافع الوهمية. قال تعالى:

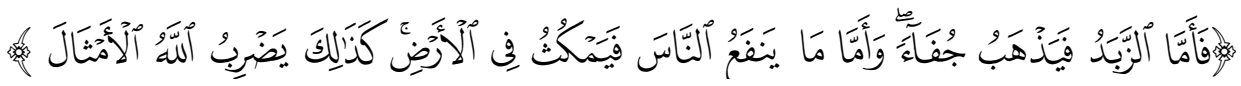




\section{أ. حقيقة الأُمَّة الواحدة، وسُنَّة الاختلاف الجارية في الناس:}

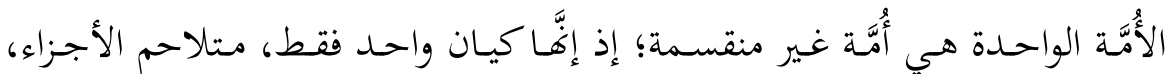

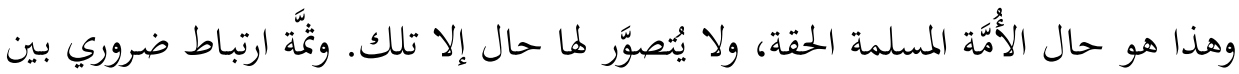

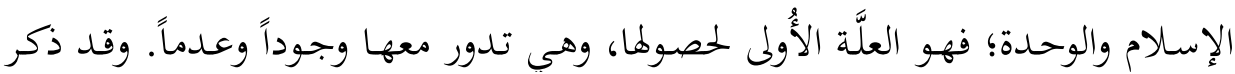

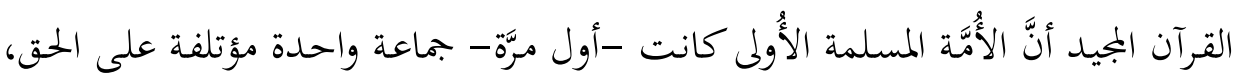

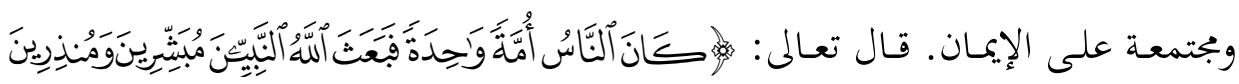

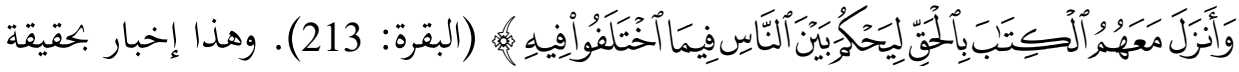

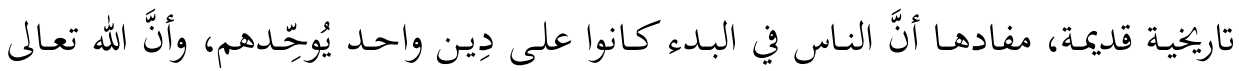

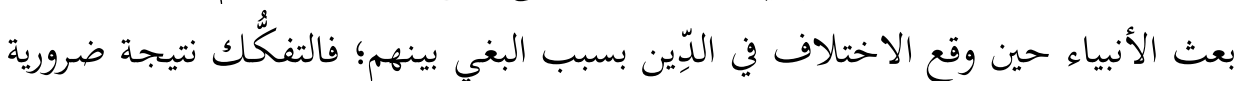

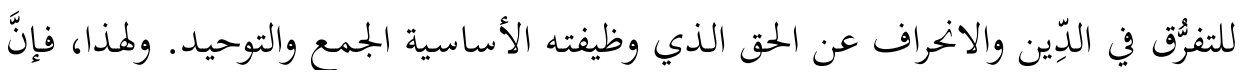

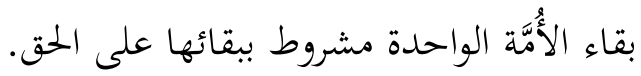

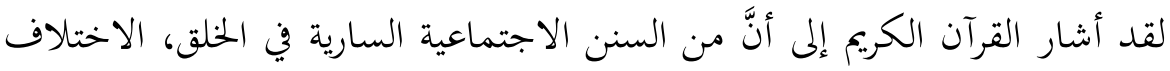

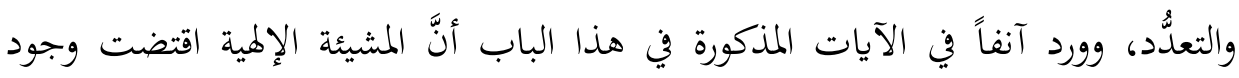

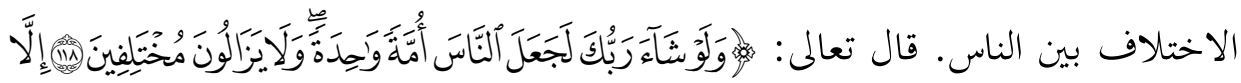

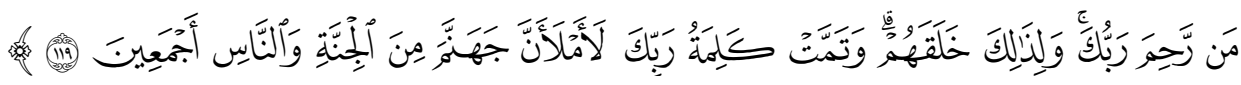

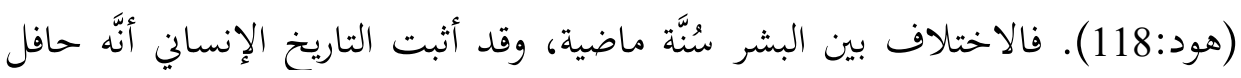

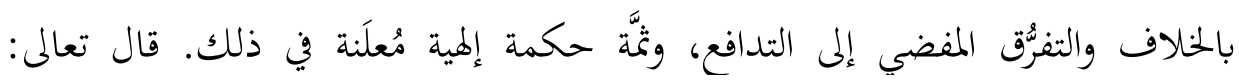

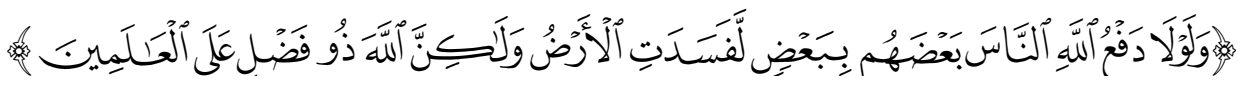
(البقرة: 251).

وحتى داخل الأُمَّة المسلمة الواحدة؛ فإنَّ الاختلاف واقع، ولا ضير في ذلك إذا لم

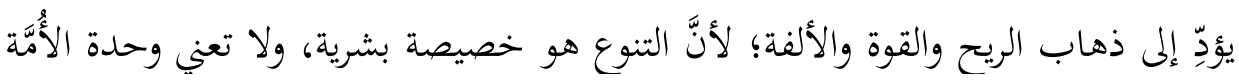

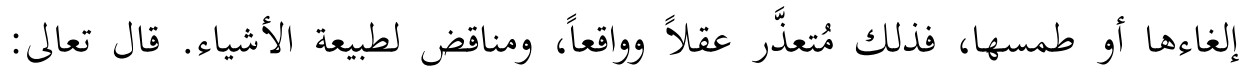

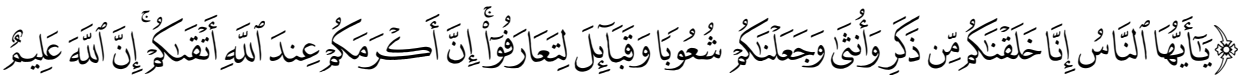

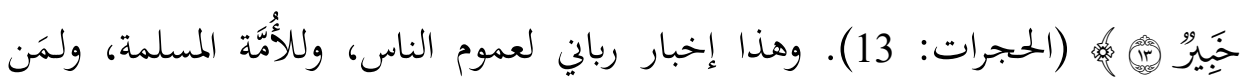




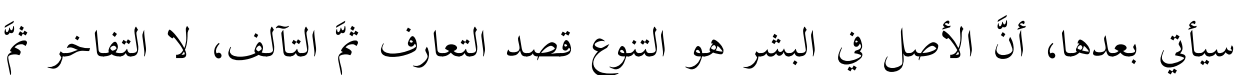

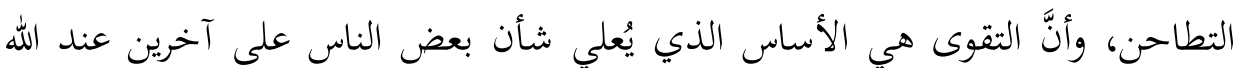

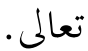

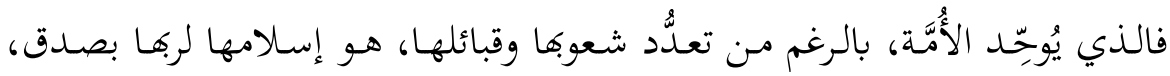

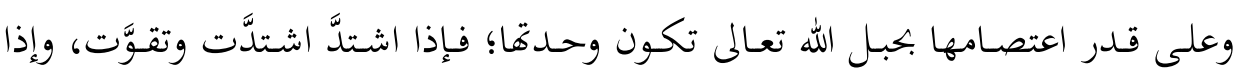

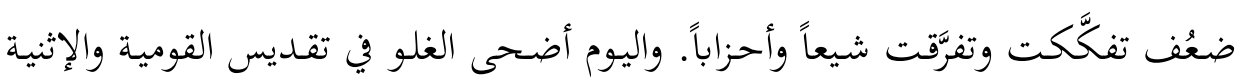

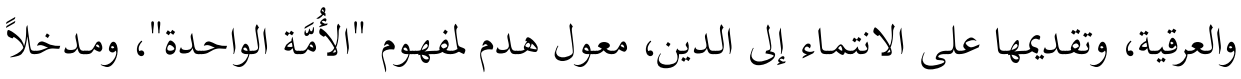

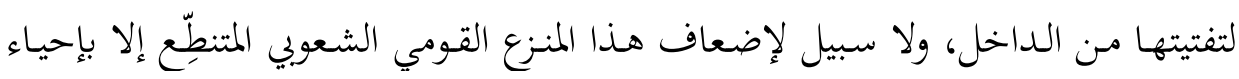

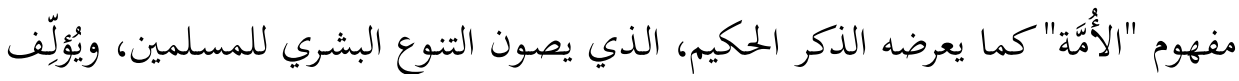

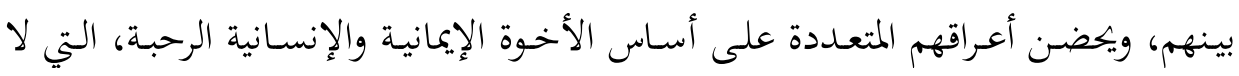
مكان فيها للتمييز والنيل من كرامة الإنسان.

\section{4. وصف "خير أُمَّة" وخصيصة الإخراج للناس والشهادة عليهم:}

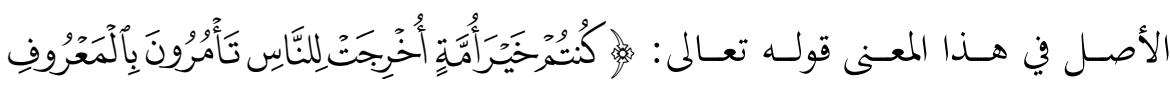

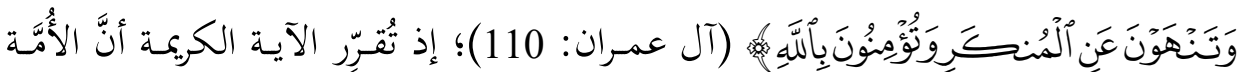

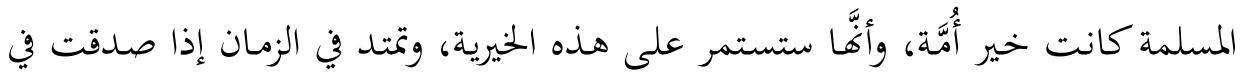

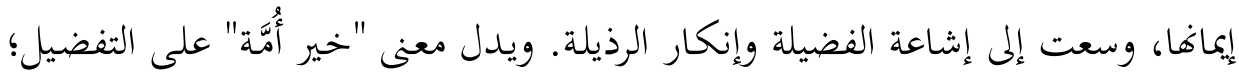

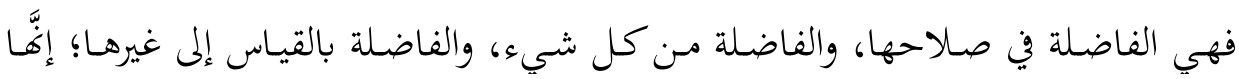

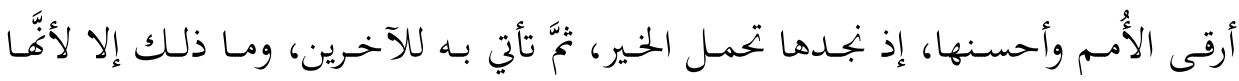

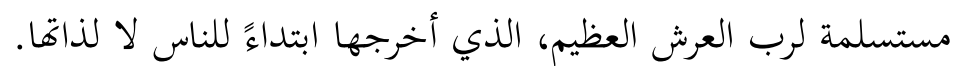
وأصل الخروج هو النفاذ عن الشيء،

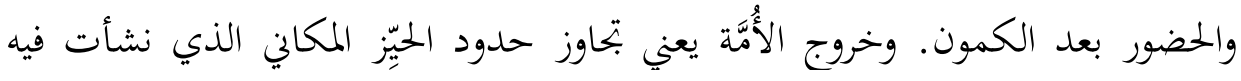

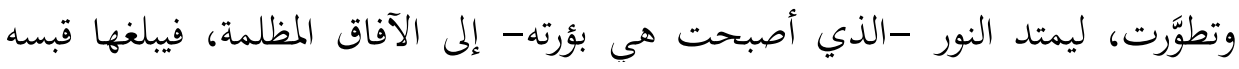

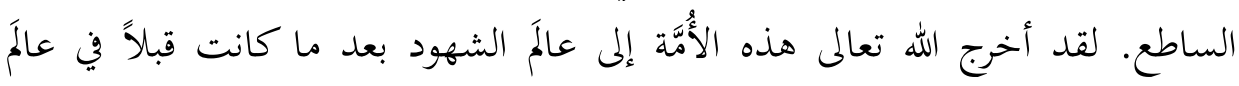

$$
36 \text { ابن فارس، معجم مقاييس اللغة، مرجع سابق، ج2، ص175. }
$$




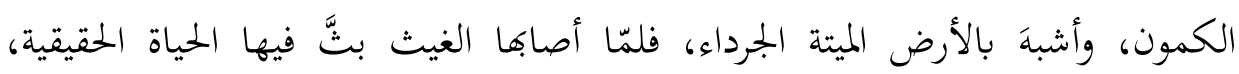

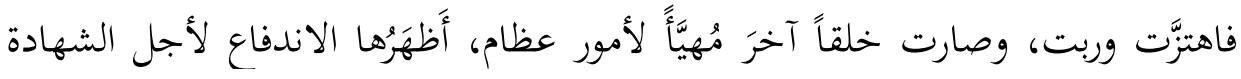

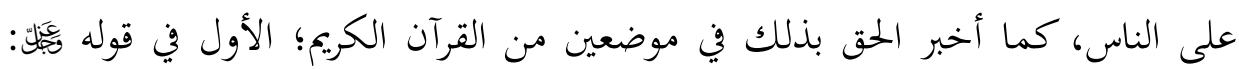

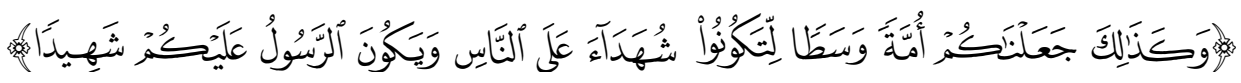

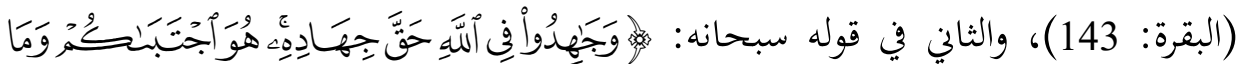

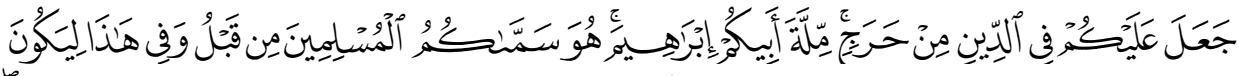

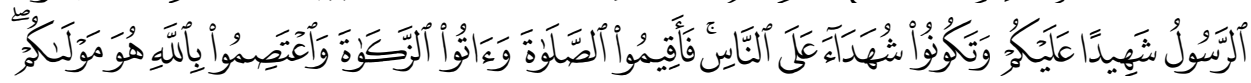

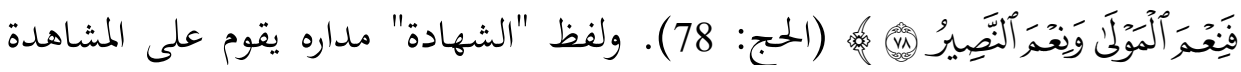

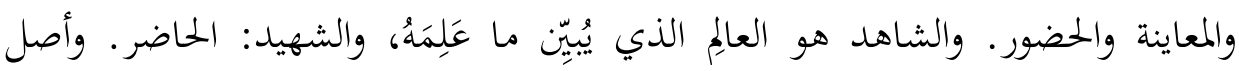

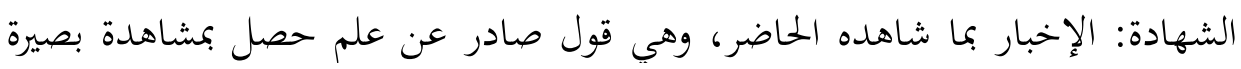

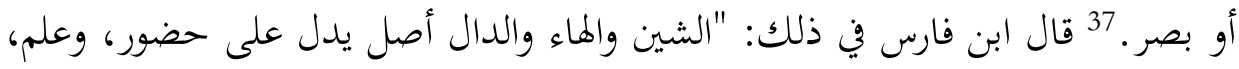

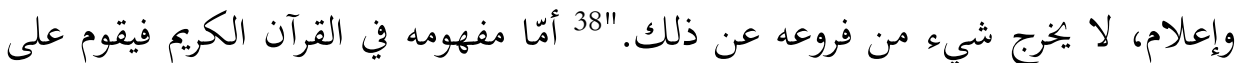

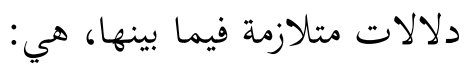

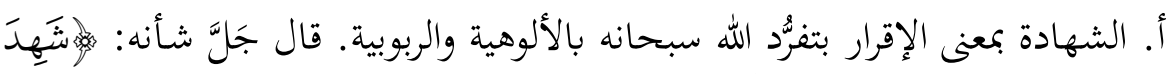

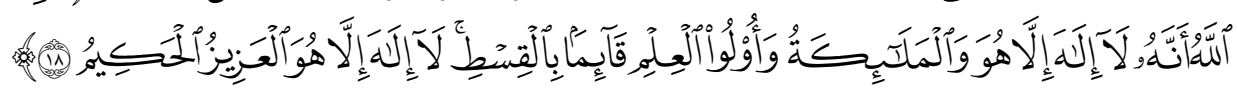

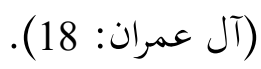

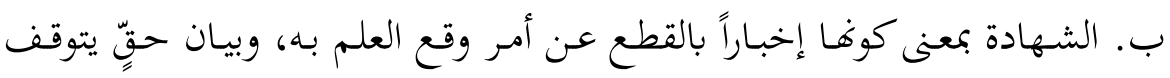

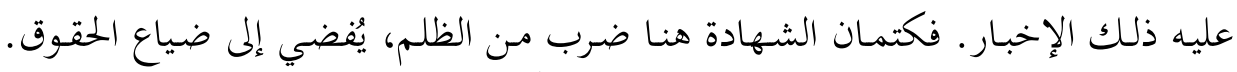

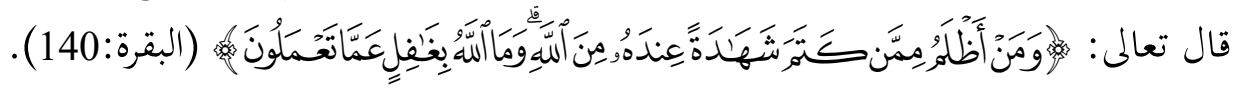

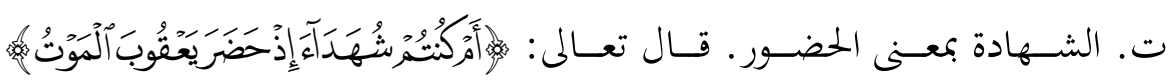

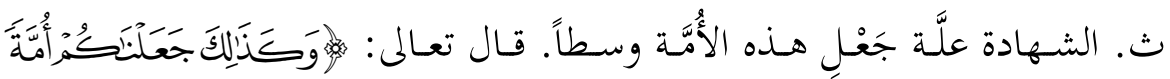

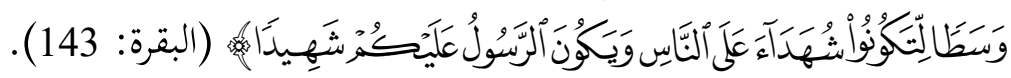

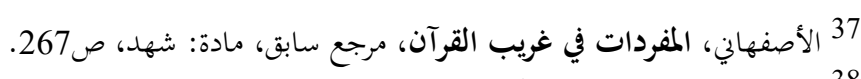

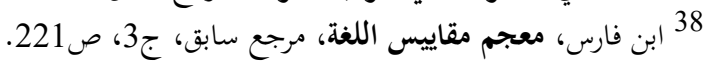


ج. الشهادة بمعنى بذل المهجة في سبيل الله، وإعلاء كلمته، ونصرة دينه، وهي مقام

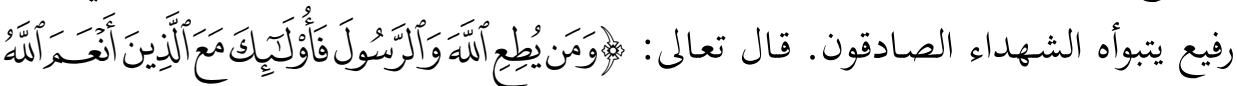

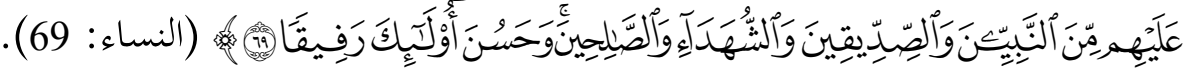

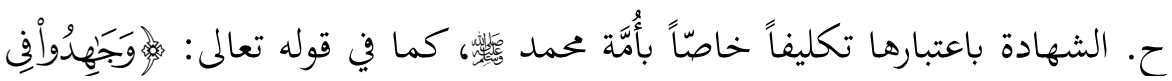

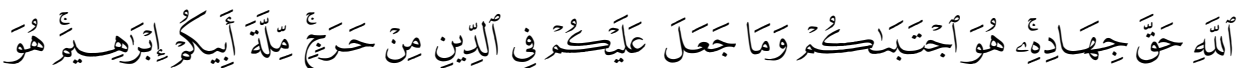

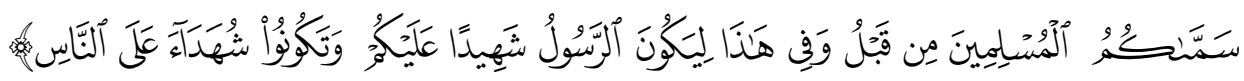

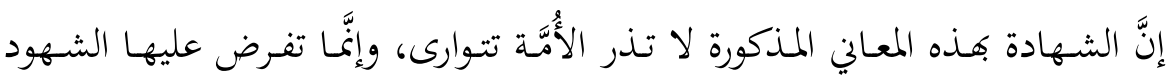
الفاعل في واقع الحياة، وتقتضي منها السعي للترقي في مراتب الإيمان الصادق، ومقامات

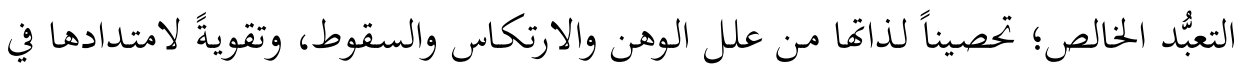

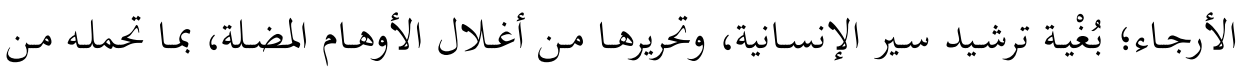

$$
\text { هدايات الوحي وموازينه. }
$$

\section{رابعاً: الثهادة على الناس وظيفة الأُمَّة الحضارية}

الشـهادة مسن حيـث هي تكليـف رباني منسوط بالأُمَّة تحمـل في جوهرهـا حقيقتـين متكاملتين؛ الأُولى غيبية، والثانية دنيوية.

1. الحقيقــة الغيبيـة: اختلـف أهـل التفسـير حـول المكـان الـذي تتحقَّق فيـه هـــه الشهادة التي تضمَّنتها الآيـة الآنف ذكرهـا؛ أهو في الدنيا أم في الآخرة؟ جـاء في البحر

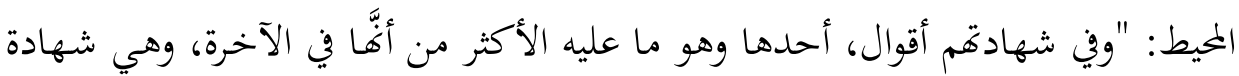

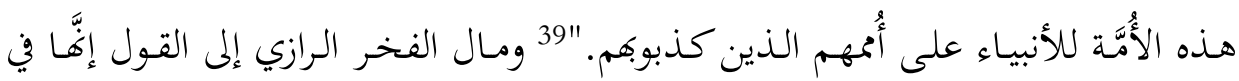

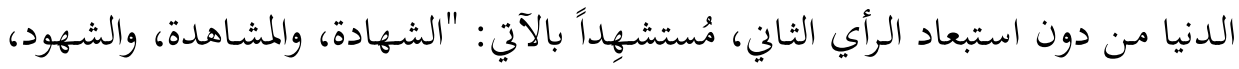
هو الرؤية، يقال: شـاهدت كذا إذا رأيته وأبصرته، ولمّاكان مان بين الإبصار بالعين وبين

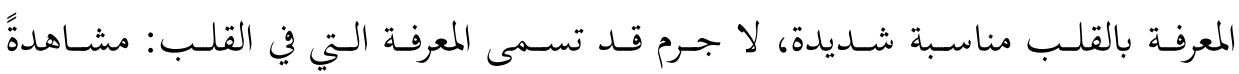

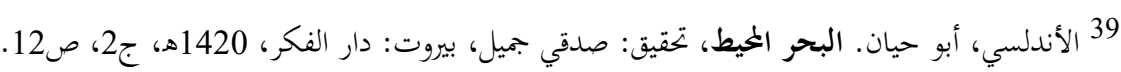




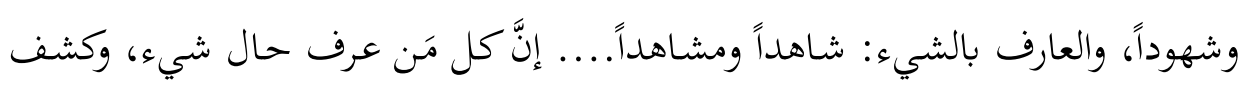

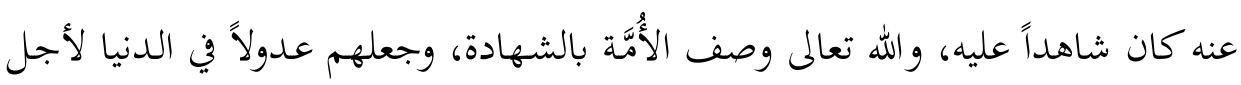

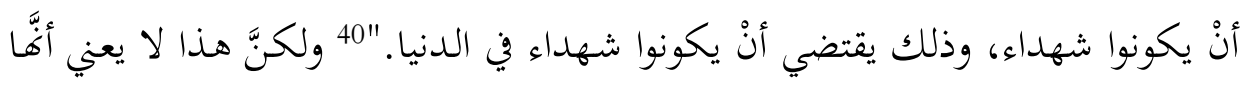

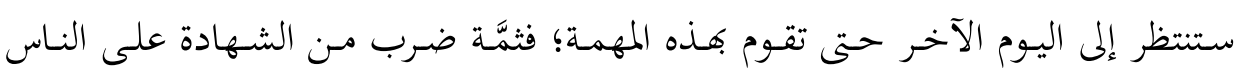
موضعها الدنيا محل التكليف.

2. الحقيقة الدنيوية: ترتبط هذه الحقيقة بعالَّ الشهادة، وتظهر في كون هذه الأُمَّة

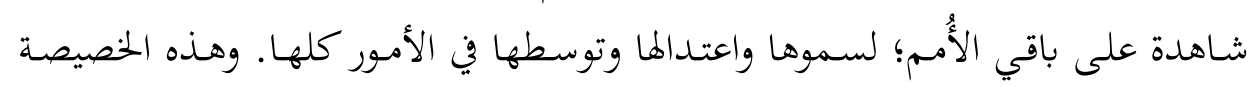

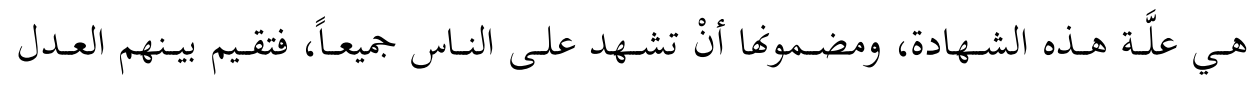

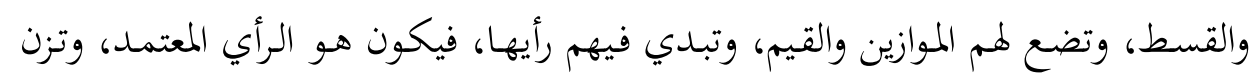

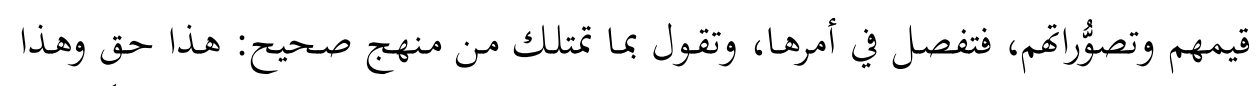

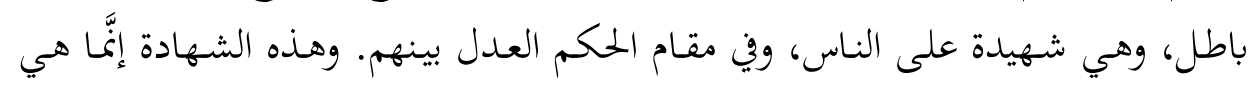
ضرب من التقويم والتصويب لمسار البشرية جيلاً بعد جيل.

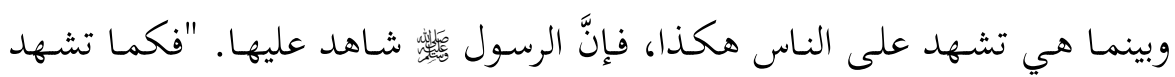

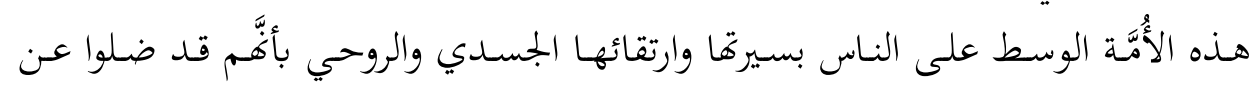

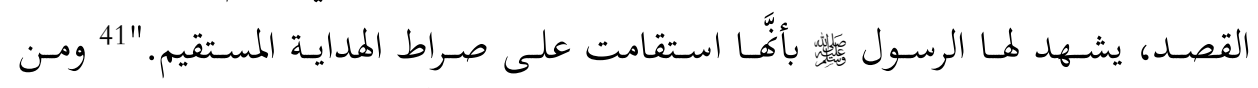

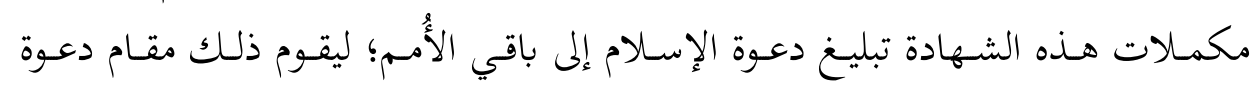

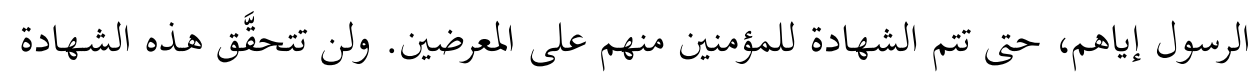

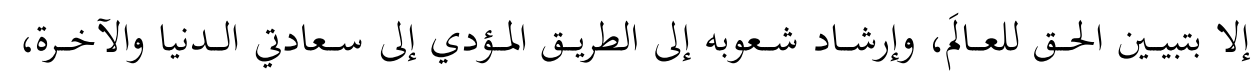

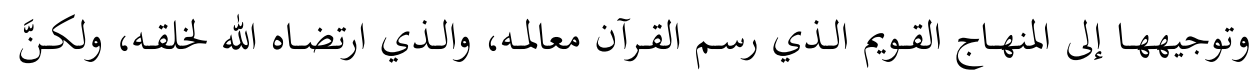

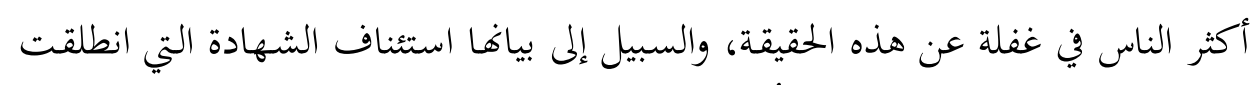

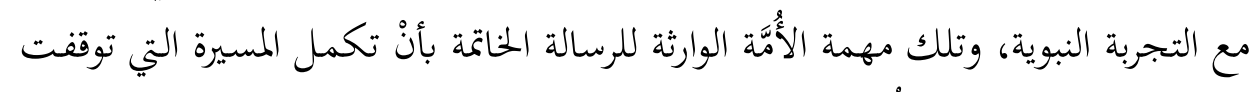
منذ قرون حين دخلت الأمَّة طور الانخسار.

40 الرازي. فخر الدين. تفسير الفخر الرازي المثتهر بالتفسير الكبير ومفاتيح الفيب، بيروت: دار الفكر، 1981م،

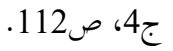

$$
\begin{aligned}
& 41 \text { رضا، تفسير المنار، مرجع سابق، ج2، ص5. }
\end{aligned}
$$




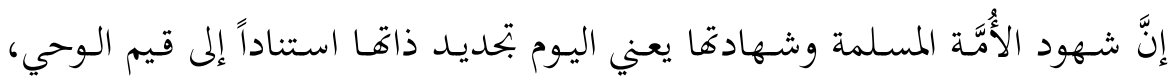
وموقعها التاريخي، وريادهما العالمية، بما تملكه من قيادة مرجعية وفكرية وتشريعية وأخلاقية،

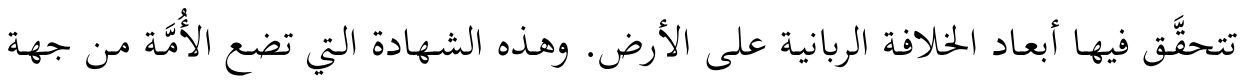
الاقتضاء في صدارة الأُمم، تتلخص أبعادها الحضارية فيما يأتي: - إيصال نور الإسلام وقبس رسالته الربانية إلى مختلف أنحاء العالَّ بجميع الوسائل المتوافرة. - الوقوف إلى جانب الحهق والعـل في القضـايا الكونيـة والعالميـة، وتقـديم النمـوذج الإسلامي عن طريق الممارسات الرشيدة العادلة.

- نصرة المُستضعَفين في الأرض، ومقاومة مظاهر الطغيان والاستكبار في العالم.42 وعلى أساس هذا التصوُر الذي تقوم عليه وظيفة الشهادة على الناس، يُمكِن تقسيم الشهادة إلى ثلاثة أقسام:

أ. شهادة العلم: مضى القول بأنَّ الشهادة هي إخبار عن أمر وقع العلم بـه، وأنَّ

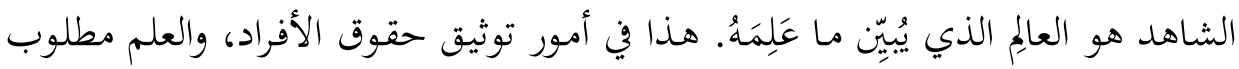

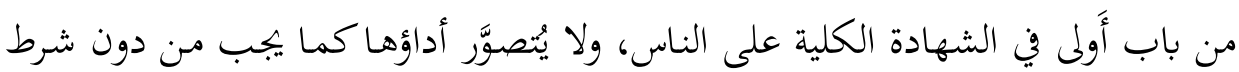

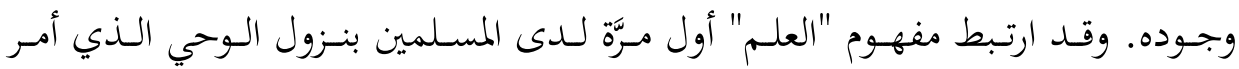

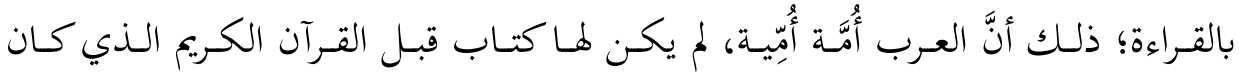

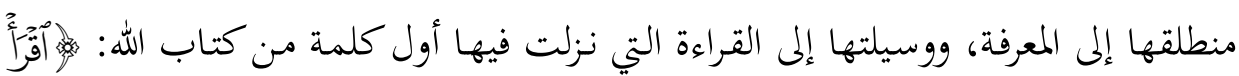

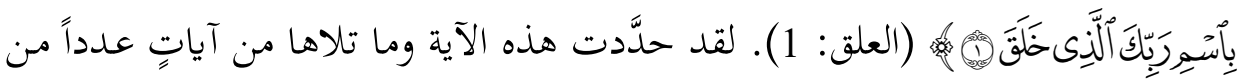
الأمور الجوهرية؛ ففيها أمر بالقراءة، وبيـان علاقة العلم بالقلم، وبيان مصدر العلم (الله

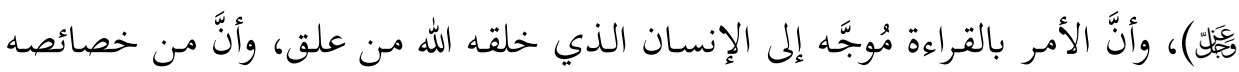
العجز؛ لذا فهو مُفتقِر في العلم إلى الله تعالى.

42 الكفيشي، عامر. مقومات النهوض الإسلامي بين الأصالة والتجديد، بيروت: دار الهادي، 2006م، ص351- 
والقراءة المطلوبـة هي القراءة باسمه سبحانه وتعالى، والقـراءة المأمور بهـا هي مفهوم

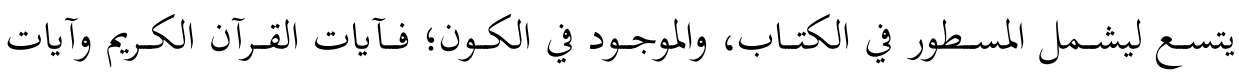

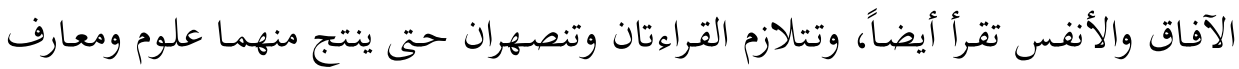

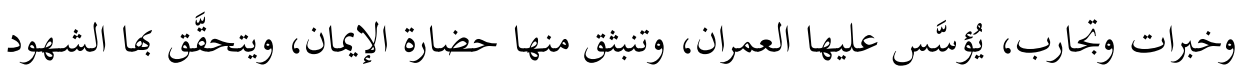
الحضاري للأُمَّة على بصيرة وخير وهدى وعلم.

وقد سبقت الإشـارة إلى أنَّ العرب وُصِفوا في القـرآن الكريم بالأُمِيسين، كمـا وصـف

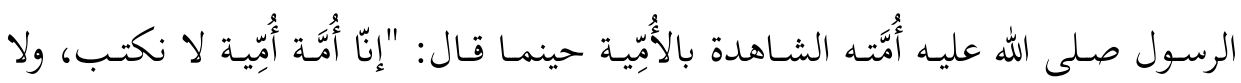

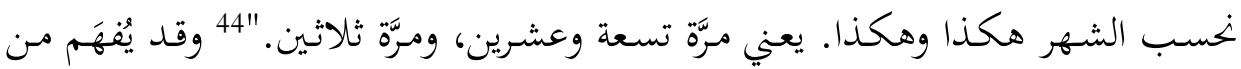

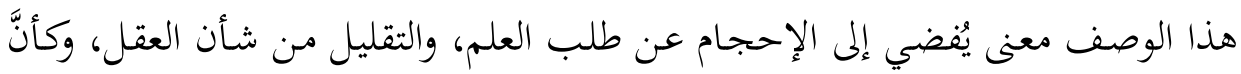

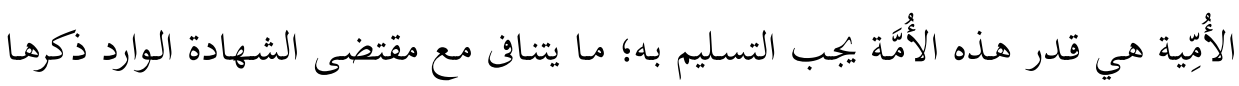

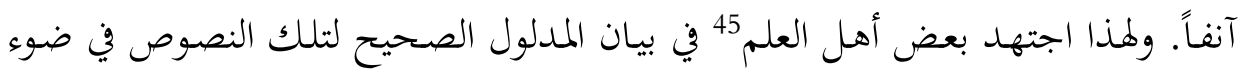

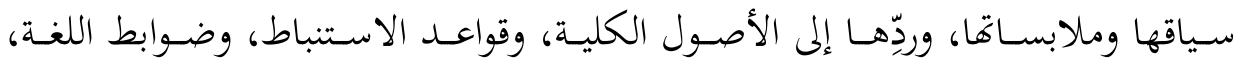

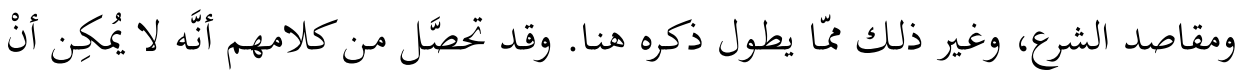

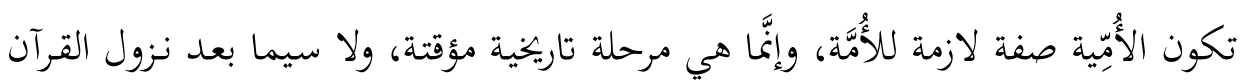
الكريم الذي احتفى بالعقل والفكر والعلم، ودعا إلى تحصيله والإمامة فيه. وفي ما يخصٌٌ إشارة الشاطبي إلى أُمِية الشريعة بقوله: "هذه الشريعة المباركة أُمِية؛ لأنَّ

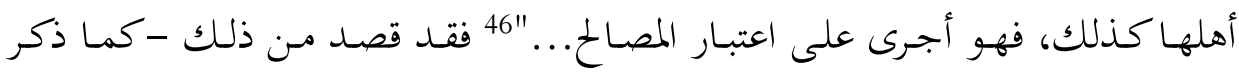

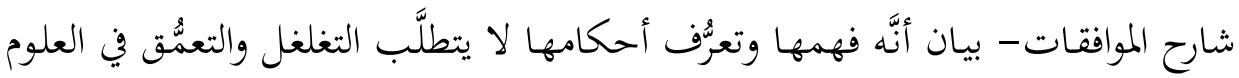

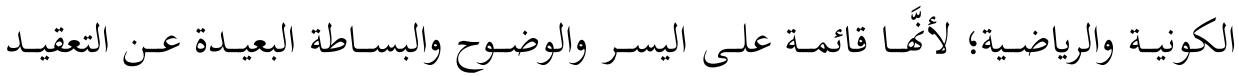

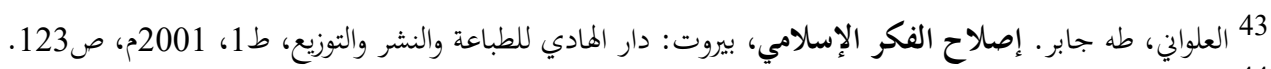

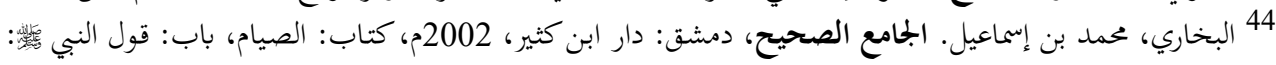

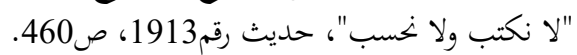

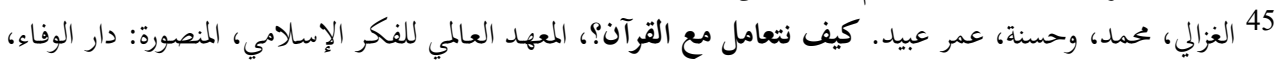

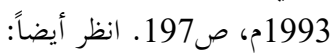

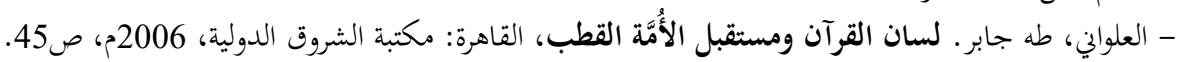

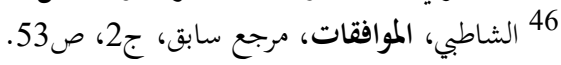


والإشـالات الصعبة. ولو كان الأمر يعني غير ذلك لاكتفى المسلمون بأُمِّيتهم وأُمِّيسة

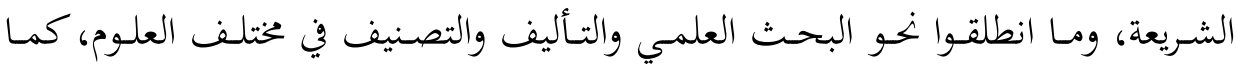

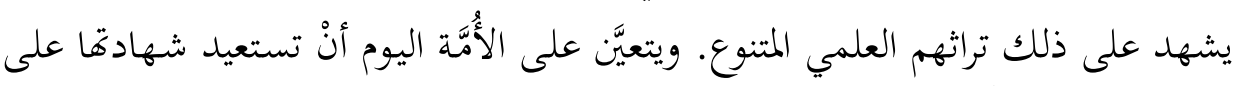

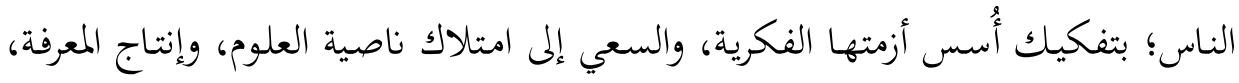
وإطلاق العنان للعقل، وإعمال الاجتهاد والتجديد في أبعاده وحقوله المختلفة. ب. شهادة التبليـغ: قال تعالى في هذا الشأن:

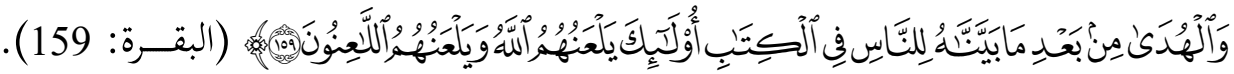
فهذه الآية تُبيِن أنَّ التبليغ أو البلاغ في التصوُّر القرآني هو أحد مبادئ الدِّين الأساسية.

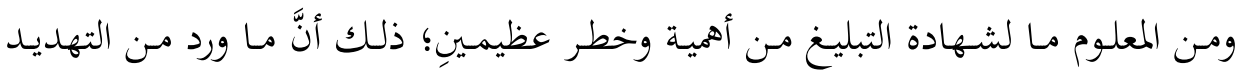
والوعيـد وتشـديد العقوبـة في كتمـان الحـق وعــدم تبليغه، لم يـرد لـه نظير، حستى في تارك الصلاة؛ مـا يدل على عِظم شأن التبليغ. فما شرعه الله من قانون المجازاة ومكافأة الناس

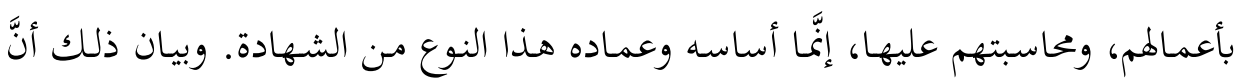

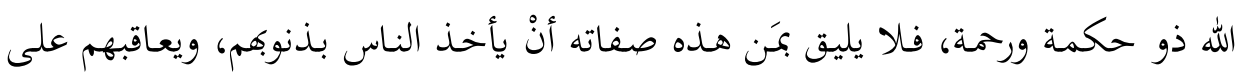

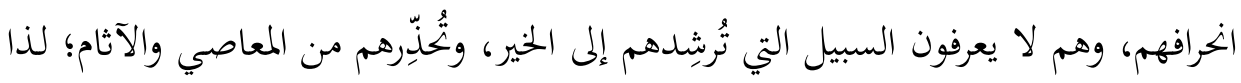

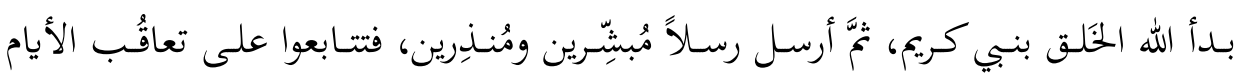

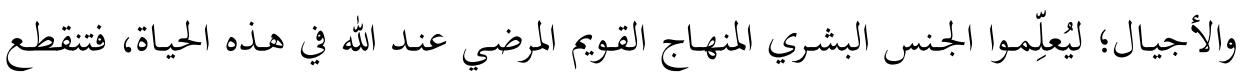

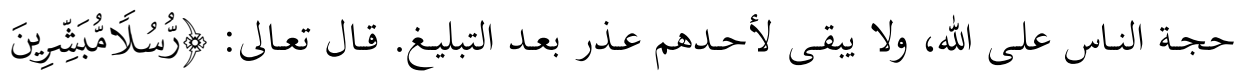

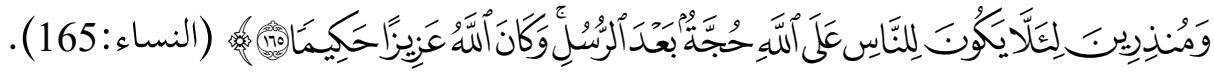
ولذذا شعر الأنبياء جميعاً بثقل هذه الأمانة، فسعوا سعيهم إلى أداء الشهادة وإبلاغ رسالاقم. ثَُّّ إنَّ الذين تلقّوا هذه الدعوة عن طريق رسل الله، وعرفوا سبيل الحقى، جعل الله منهم أُمَّة ورثت ذلك إنك التكليف، ونابت منابهم في تحمُّل هذه التبعة الواجبة المحتومة على الذين يدينون بالإسلام، ويَعُدّون أنفسهم من أفراد هذه الأُمَّة. 47 


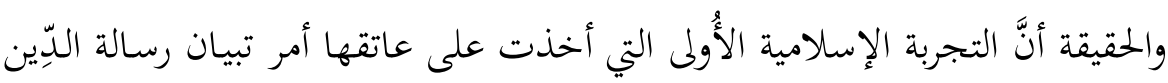

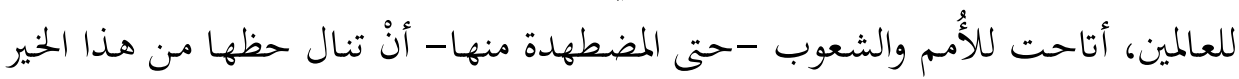

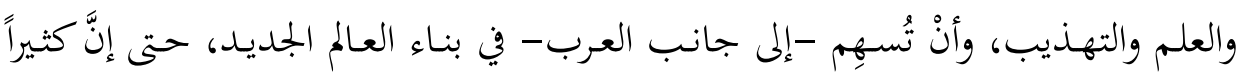

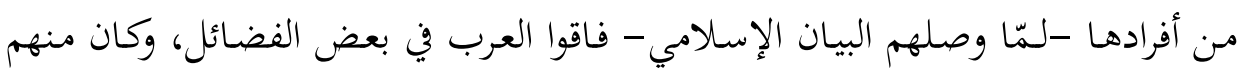

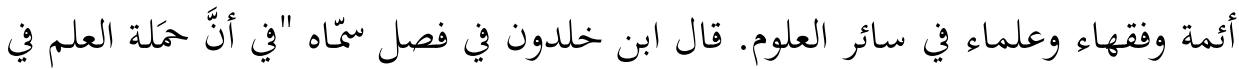

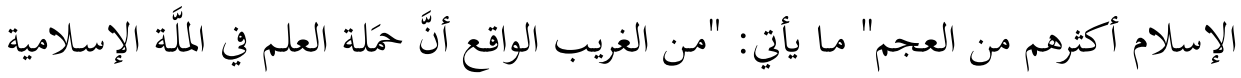

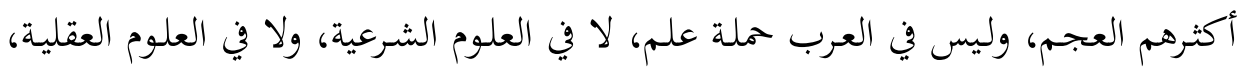

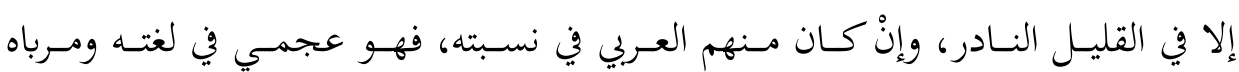

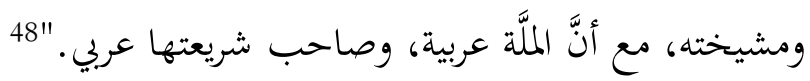

وهـذا الواقع مـاكـان لـه أنْ يتحقَّق مـن دون فـوض المسـلمين الأوائل بـواجبهم في

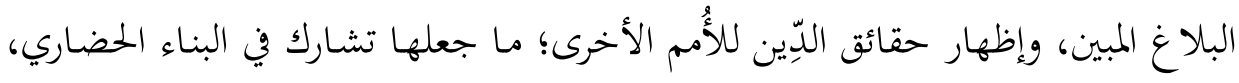

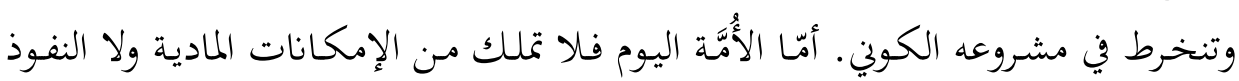
العالمي ما يُمكِنها من فتح بجالات حيوية خارج حدودها، والشيء الوحيد الذي قد يلفت انتباه العالمَ إليها هو الدعوة والمضامين الحضارية الفريدة التي تحملها؛ فإهمالها الدعوة شوَّه وجهها العالمي، وحرمها من الشعور وحدها بالتفرّد الذي كان قاب قوسين أو أدنى. ت. شـهادة النطبيق: يُقصَّد بـذلك تمثُّل كل الأصول، والمبـادئ، وشعب الإيمان،

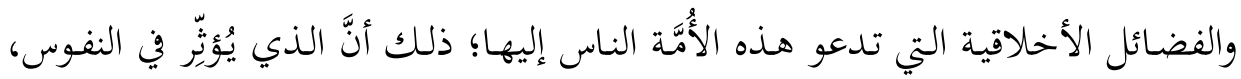

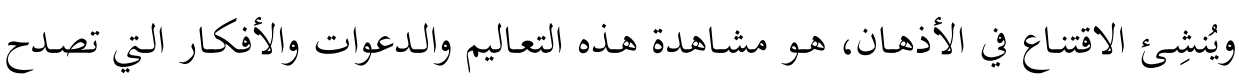

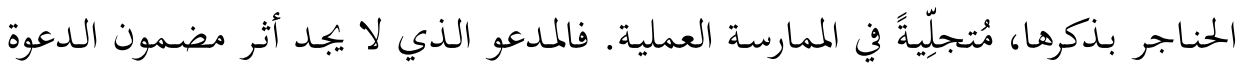
في تصرفات الداعية يفقد الشعور بصدق مَن يدعوه، وكذا مصداقية الدعوة نفسها، وفي

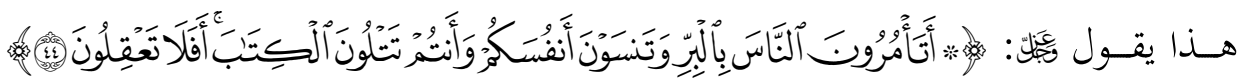

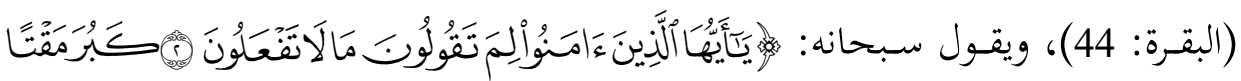

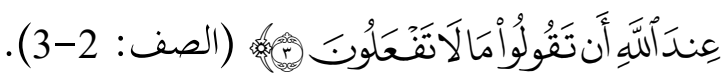
48 ابن خلدون، عبد الرحمن. المُقدِّمة، بيروت: دار إحياء التراث العربي، د.ت، ص543. 
ويندرج تحت ذلك كل مخالفة بين القول والعمل؛ لأنَّ الذي يستمرئ هذا الأمر لا

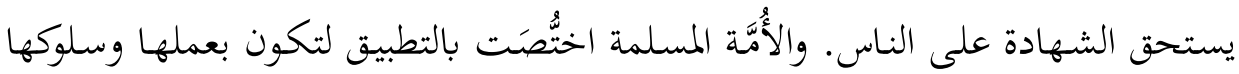

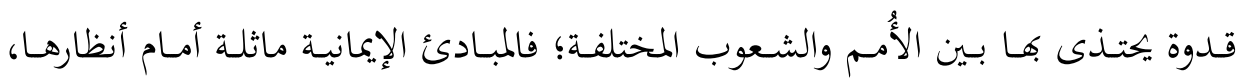

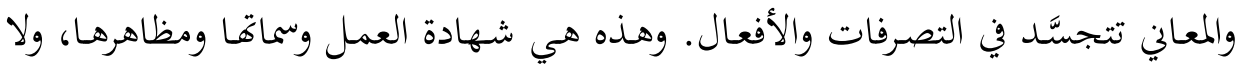

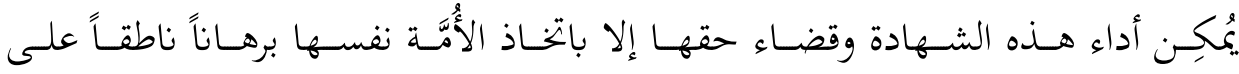

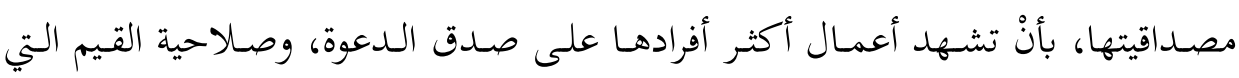

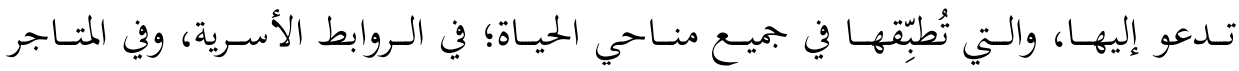

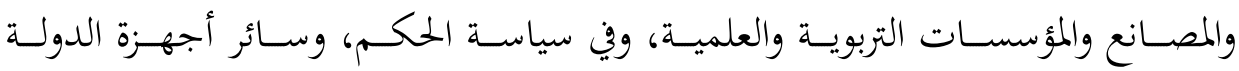
والمجتمع.

\section{خاتمة:}

انتهينا في هذا البحث إلى أنَّ الله تعالى قد شرَّف الأُمَّة المسلمة الواحدة الوسط أنْ

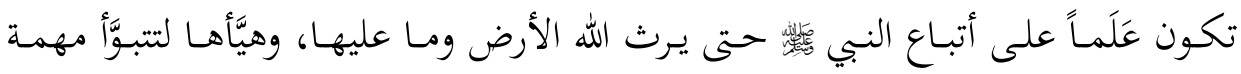

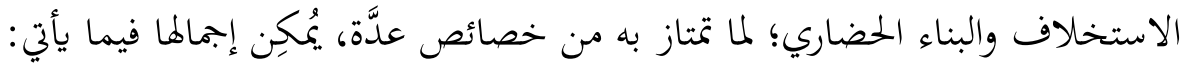
- التسليم لرب العالمين الواحد الأحد، والخضوع لمنهجه ودينه الحق. - الوحـدة مـن حيـث الانتمـاء إلى ديـن الإسـلام، بوصفه العنصـر الجـامع لمكوِّناتها المختلفة، وروافدها المتعددة.

- الخيريـة؛ فهي خير أُمَّة أُخرِجِت للنـاس. وهذه الخيريـة مشروط تحقُّقها بالإسهلام

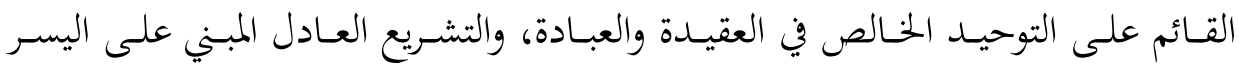

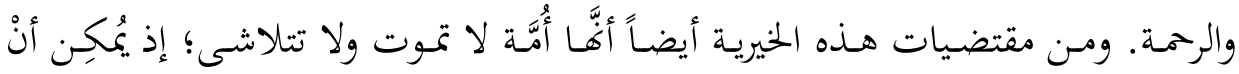

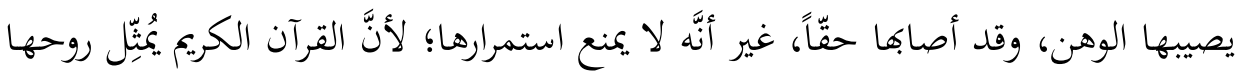

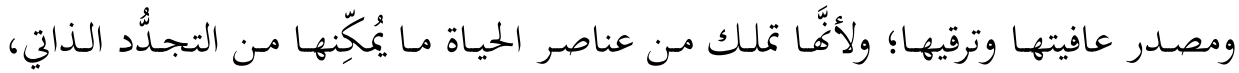
ويمنحها القدرة على النهوض من جدئد. 


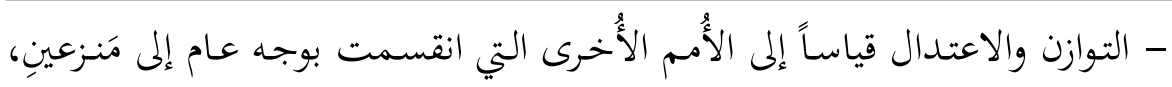

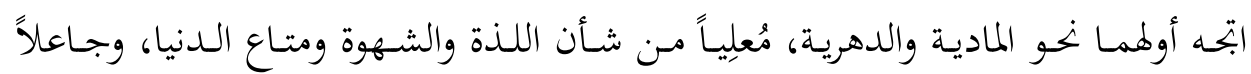

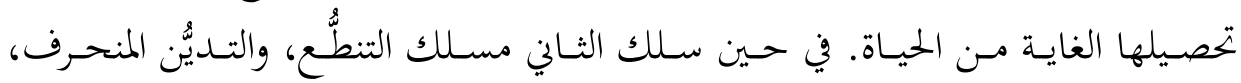

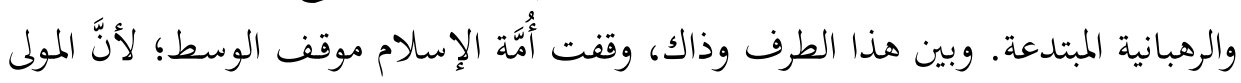

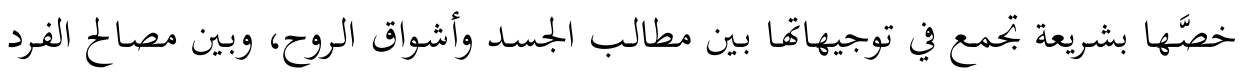

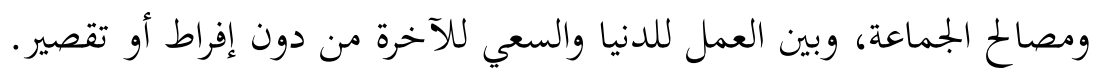

- التكليف؛ فهي تحمل أمانة عظمى، ولها رسالة في الوجود، وعليها مسؤولية إزاء

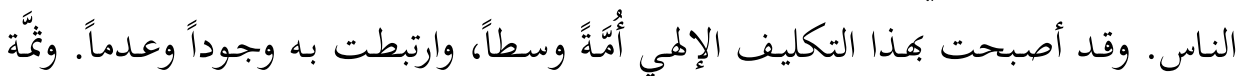

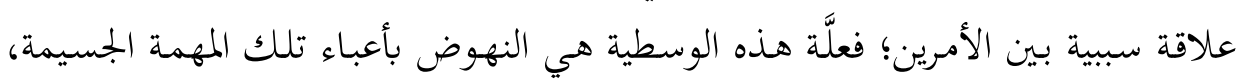

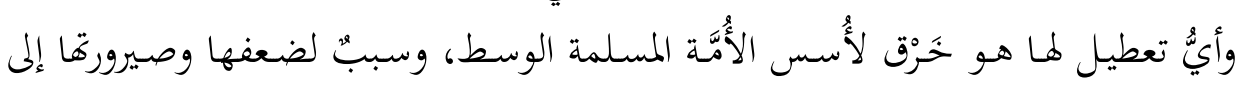
الانخطاط. 